
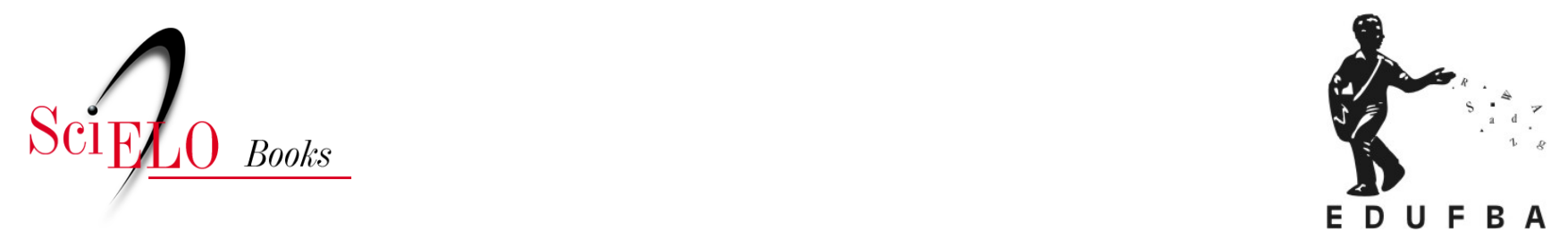

\title{
Por que, como e de que riem as mulheres da antologia?
}

\author{
Alba Valeria Tinoco Alves Silva
}

\section{SciELO Books / SciELO Livros / SciELO Libros}

SILVA, A.V.T.A. Por que, como e de que riem as mulheres da antologia?. In: Deus e o diabo no humor das mulheres: contos, casos e crônicas com humor escritos por mulheres [online]. Salvador: EDUFBA, 2015, pp. 101-167. ISBN: 978-85-232-1868-3.

https://doi.org/10.7476/9788523218683.0005.

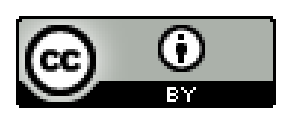

All the contents of this work, except where otherwise noted, is licensed under a Creative Commons Attribution $\underline{4.0 \text { International license. }}$

Todo o conteúdo deste trabalho, exceto quando houver ressalva, é publicado sob a licença Creative Commons Atribição 4.0. 


\section{.}

हाँ

\section{Por que, como e de que riem as mulheres da antologia?}

\section{Por que riem as mulheres?}

Hilda Hilst ${ }^{251}$ explica em seu livro de crônicas, Cascos \& carícias, a razão de ter se voltado para o humor depois de ter escrito com austeridade suas ficções, seu teatro e sua poesia. Ela diz, através de um poema, que optou pela própria salvação:

O louco se fechou ao riso

Se torceu convulso de fingida agonia

E como se lançasse flores à cova de um morto Atirou-me os guizos.

Por quê? Perguntei adusta e ressentida.

- Ó senhora, porque mora na morte

Aquele que procura Deus na austeridade. ${ }^{252}$

Sua escolha pelo riso se deu porque ela se tornou pessimista quanto à salvação do homem, sendo acometida de expansões de riso sempre que se deparava com textos "esperançosos" 253 , como se tivesse

251 HILST, H. Cascos e carícias. São Paulo: Nankin, 1998. p.15.

252 HILST, H. Do desejo. São Paulo: Pontes: 1992. p.65.

253 HILST, 1998. p.15. 
desistido de buscar no alto o sentido das coisas e tivesse passado a olhá-las de baixo, como convém ao método cômico. Em Teje presa!, por exemplo, ela propõe a criação de um bordel geriátrico, onde as pessoas pagariam para ver velhinhos nus, talvez para rir um pouco. Ela própria diz que adoraria ver Einstein e Bertrand Russel nus, ela lhes apontaria as partes e lhes diria: "E isso aqui, o que é? É aquilo. Não acredito, ficou assim é? E riríamos, riríamos"254. Os textos dessa coletânea são uma mistura de observações sobre o cotidiano, fábula, poesia, paródia, citações, imitações de Dr. Fritz, tudo isso costurado com erudição, indignação e deboche.

Esse caráter híbrido dos textos de Hilda Hilst atualiza, na narrativa, o que Cleise Mendes observa na dramaturgia contemporânea, cujas tendências dominantes não são as formas canônicas da tradição cômica (sátira social, comédia de costumes, comédia de intriga, de caracteres etc.), mas um certo gesto, um certo olhar, próprios da comicidade, que promovem todo tipo de hibridizações, de fusões, de inversões, de contaminação entre procedimentos antes circunscritos a obras de dramaturgia bem diversas ${ }^{255}$.

Dois aspectos dessa afirmação são produtivos para a análise que aqui se pretende empreender. Um deles é que, de modo similar ao que ocorre na dramaturgia e que se pode observar nas crônicas de Hilst, se pressupõe um contágio de modos e procedimentos na construção do cômico nas formas narrativas. Ou seja, acredita-se que, subjacente ou superposta ou imbricada a qualquer procedimento específico que ressalte dos textos aqui observados, há uma série de outros igualmente relevantes. O outro aspecto é que tal fusão ou imbricação de procedimentos e formas é promovida por um certo gesto, um certo olhar, e, no caso das narrativas de humor, vale acrescentar, uma certa voz.

Aliada ao olhar, que estabelece a aproximação ou distância do objeto, e ao gesto, que escolhe traços mais ou menos favoráveis do que está sendo observado, cabe à voz dissimular, enunciar ou refletir sobre a regra sobre as situações sociais, nas quais a personagem

254 HILST, 1998, p. 44.

255 MENDES, 2001, p. 123. 
ou mesmo o leitor, quando é chamado à cena, deveria acreditar ${ }^{256}$. É possível mostrar o que se entende por esse olhar, gesto e voz num trecho de Só para raros, de Hilda Hilst:

Em decorrência da fetidez que assola o País, só tenho vontade de escrever textos sórdidos, coléricos, cínicos, degradantes ou estufados de um humor cruel e até me permitiria sugerir ao caríssimo editor que bolasse uma maneira de a crônica ser fechada assim como certas revistas envelopam um pequeno mimo, uma tirinha de seda, um saquinho de perfume, e envelopariam minha crônica e colocariam sobre ele uma fitinha negra 'censurado', ou 'só para cínicos', ou 'só para fazer sorrir os desesperados'. Ou quem sabe, à maneira de Hesse: 'só para raros'. Porque convenhamos há pulhas em demasia. E enquanto não se resolve isso da minha crônica-envelope, não consigo escrever nada de coerente e agradável, nada que seja uma 'crônica'. ${ }^{257}$

A cronista admite que, diante do absurdo e do grotesco do que ela vê, o seu tom só pode ser o do destempero, do qual ironicamente ela quer poupar os olhos ou ouvidos mais sensíveis, propondo uma espécie de capa protetora para o seu texto. É como se ela, mesmo dizendo que optou pelo riso como salvação, não conseguisse apenas se divertir, mas quisesse usá-lo como uma forma de denúncia, como uma sátira no sentido que Frye dá ao termo de uma "ironia militante"258.

Assim como Hilda Hilst, outras autoras brasileiras optaram pelo humor, seja como salvação seja como elemento fundamental ou acessório para a construção dos seus textos. É o que diz Leila Ferreira na introdução do seu livro Mulheres: por que será que elas...?: "Mas se há uma coisa em que acredito é no humor. Amo ouvir casos engraçados. Este livro é a soma de várias conversas que tive com

256 Cf. ECO, 1984, p.351.

257 HILST,1998, p. 80.

258 FRYE, 1973, p. 219. 
mulheres que têm senso de humor e aprenderam a rir delas próprias e de suas adversidades." 259

\section{Como e de que riem as mulheres?}

Como foi dito na introdução deste trabalho, os objetivos centrais deste capítulo são analisar, com o auxílio de narrativas produzidas por escritoras brasileiras, como os procedimentos de construção de humor são utilizados nesses textos e verificar se é verdadeira a hipótese de que esse humor tem como alvo principal a própria mulher - e aquilo que a cerca mais intimamente, o corpo, os filhos, o relacionamento amoroso e o homem enquanto parceiro nessa relação - ou se seu escopo é mais abrangente.

A organização do capítulo, contudo, ficou melhor na ordem inversa. Os textos são apresentados a partir do alvo para o qual o humor é direcionado, e a análise dos mecanismos de construção de humor, neles utilizados, tem como principal fio condutor os procedimentos organizados por Propp ${ }^{260}$. Melhor do que "fio condutor" seria dizer "pavio detonador", porque é com certa cautela que se pretende lidar com termos como "categorias" e "modelos", mas o risco será assumido porque, apesar do seu feitio taxonômico, os recursos que Propp arrolou, tais como o exagero, a paródia, a caricatura, continuam presentes na construção do texto humorístico. O que nesse autor se encontra datada é a ênfase na motivação derrisória do humor, é a ideia de que ele está a serviço de uma missão "educativo-punitiva" de todo aquele que não se enquadra em algum modelo estabelecido de beleza ou de comportamento, concepção de certa forma redutora dos recursos que o humor disponibiliza e da visão de mundo que ele propicia. Sendo assim, a taxonomia proppiana será, sempre que necessário, comentada à luz de trabalhos mais recentes, como os de Hutcheon ${ }^{261}$ e de

259 FERREIRA, 2007. p. 10.

260 PROPP, 1992.

261 HUTCHEON, 2000. 
Mendes ${ }^{262}$, mas sem desqualificar as afirmações do autor nem tampouco converter suas categorias "num modelo revisto e atualizado de Propp voltado para o humor escrito por mulheres". O compromisso aqui é menos com a conversão do que com a diversão ${ }^{263}$.

O que se pretende, pois, é parodiar o modelo de Propp, não no sentido de contrapô-lo ou caricaturá-lo (para = "contra"), mas de situar a análise ao longo (para = "ao longo de") da taxonomia proppiana, num jogo de vai e vem entre cumplicidade e afastamento ${ }^{264}$. Ali onde Propp considera ridículo o homem com aparência de animal, pode situar-se a mulher que solta suas feras com o seu "sutiã de vaca e sua calcinha cachorrona"; onde ele situou o homem-coisa, automático, mecanizado, tão caro a Bergson ${ }^{265}$, situa-se a mulher com a sua maleabilidade polimorfa.

E, como última ressalva, cumpre dizer que essa separação dos fios que compõem a meada do humor, que tem o objetivo de entender os seus procedimentos e os critérios de escolha de textos que o exemplifiquem, leva em consideração, no âmbito da narrativa, a ressalva de Cleise Mendes de que tal "separação deve ser feita com cuidado quando se lida com textos concretos de comédias, pois a dinâmica dramática cria um tecido em que situações, personagens e diálogos cooperam na obtenção do efeito cômico"266.

262 MENDES, 2001,.

263 Ibid., p. 332-334.

264 HUTCHEON, L. Teoria da paródia: ensinamentos das formas de arte do século XX. Lisboa: Edições 70, 1985. p. 48.

265 BERGSON, 2001. p. 7-15.

266 MENDES, 2001, p. 123-124. 


\section{Riem dos próprios papéis}

\section{Carmen da Silva, o feminismo é uma festa}

O texto O feminismo é uma festa não é exatamente um conto, caso ou crônica, mas foi escolhido para ser o primeiro a ser citado, porque é um fragmento biográfico da vida da autora, Carmen da Silva, jornalista, escritora e pioneira do movimento feminista no Brasil. O trecho trata de um desfile realizado pelas militantes do dito movimento no dia 8 de março de 1983, no Rio de Janeiro. Em homenagem ao Dia da Mulher daquele ano, cerca de 20 mulheres decidiram se travestir dos estereótipos através dos quais as mulheres muitas vezes são vistas: a normalista, a virgem inocente, a mãe zelosa, a solteirona, a puta, a filha de Maria. ${ }^{267}$

Mesmo não se tratando de uma obra de ficção stricto sensu, achou-se importante escolhê-lo para figurar na antologia, porque ele relata justamente a realização de uma manifestação pública de senso de humor por parte das mulheres e, mais particularmente, das feministas que, como o próprio texto diz e como se viu no capítulo 2, são tidas como incapazes de perceber e de fazer humor:

Somos acusadas, entre mil outras características negativas, de falta de senso de humor. Isso porque reagimos a certas piadas e galhofas sobre a condição feminina com a mesma veemência com que se reage à menção da corda em caso do enforcado ou a gracejos sobre fornos de gás num lar judeu: sabemos onde nos aperta o sapato - não necessariamente 0 sapatão - e ninguém ri de pé doendo. ${ }^{268}$

O texto - além de ser um testemunho de que as mulheres são capazes de reconhecer e de rir dos papéis ridículos, cruéis e desqualificadores,

267 SILVA, C. Histórias híbridas de uma senhora de respeito. São Paulo: Brasiliense. 1984. p. 184-187.

268 ibid, p. 184. 
que lhes são atribuídos e que elas, voluntária ou involuntariamente, encarnam - é também um relato feito com humor:

Leila encarnava a maternidade plenamente realizada, com uma elaborada fantasia de Mãe Enlouquecida - e não havia pormenor que não acentuasse esse enlouquecimento. Não sei onde ela desencavou uma blusa e uma saia que, além de nada terem a ver uma com a outra, eram a mais perfeita representação do anódino: amorfas, de cor e desenho indefinidos, apertavam aqui, sobravam ali, enrugavam-se acolá. Uma rede amarela cobria-lhe a cabeça eriçada de rolos, o pente e a escova enfiados no cós do avental denunciavam que a boa intenção de pentear-se tivera de ser protelada em favor de exigências mais urgentes: mãe que se preza não-tem-um-minuto-para-si. ${ }^{269}$

A narradora, ao descrever a composição de cada um dos papéis representados, mostra uma espécie de caricatura viva de cada um deles.

\section{Elisa Palatnik, Vida de pediatra não é bolinho, não}

O papel de mãe é, também, o tema de Elisa Palatnik em Vida de pediatra não é bolinho, não $0^{270}$. O texto é construído em torno das ansiedades e temores do que parece ser A Mãe de Primeira Viagem e do inferno em que ela transforma a vida do pediatra do filho:

- Alô, dr Felipe.

- Alôoorg...Rita, são quatro da madrugada. É a sétima vez que você me liga hoje.

269 SILVA, 1984, p. 185.

270 PALATINIK, E. Vida de pediatra não é bolinho não. [S.1.], [200-?]. Disponível em: <http:// www.releituras.com/epalatnik_pediatra.asp>. Acesso em: 24 abr. 2007. Grifo do autor. 
Seus cuidados são apresentados como obsessivos, exagerados, criando a caricatura de uma mãe excessivamente zelosa, ou do que Carmen da Silva chamou, no texto anterior, de "Mãe Enlouquecida". Caricatura que beira o grotesco pela falta de limites de Rita, a mãe da crônica, que não poupa o pediatra dos detalhes mais escatologicamente pitorescos das secreções do filho Dudu:

- Fala, Rita...

- É sobre a meleca do Dudu. Ela está completamente verde e...

- Claro que está verde! Eu nunca vi meleca roxa! Nem azul! Sempre foi verde! Antes de Cristo, ela já era verde. Os romanos, os egípcios...todos tinham melecas verdes! Cleópatra tinha meleca verde!

- Acontece que não é só uma questão de cor. É a quantidade. Pro senhor ter uma ideia, eu já juntei um balde e dois tupper-wares só de catarro.

- Um balde e dois tupper-wares??! 271

As expectativas, temores, responsabilidades relacionados à primeira maternidade devem gerar cuidados e preocupações por parte da mulher, o que pode ser ainda mais aterrorizante quando se percebe que os conhecimentos necessários para dar conta das necessidades da criança recém-nascida são, em sua maioria, entendidos como "naturais", a mulher supostamente nasceria sabendo de tudo que é necessário saber para cuidar do filho. Não é de admirar, portanto, o número de anedotas que as próprias mães contam sobre o exagero dos temores e cuidados e o assédio ao pediatra ou à própria mãe, quando do nascimento do primeiro filho. A graça do texto, que descreve a criatividade das peripécias de Rita para garantir a integridade física de Dudu, está justamente no fato de que todo mundo já ouviu uma história parecida - há casos verídicos de uma mãe que só dava banho no primeiro filho com água mineral e outra que fez um mostruário das fezes da criança para mostrar ao pediatra. É como se a

271 PALATINIK, [200 - ?]. 
narradora percebesse e retratasse com um certo exagero a pitada de absurdo ou de loucura do cotidiano das pessoas ditas normais.

\section{Nina Horta, Ai que implicância!}

Nina Horta escreve uma coluna para a seção de gastronomia do jornal Folha de S. Paulo; seus textos giram em torno da comida e assuntos correlatos, bem como dos usos e costumes relacionados ao tema, com leveza e um toque de humor como convém à crônica.

O texto Ai que implicância"272 foi escolhido, porque, além de usar o humor para tratar dos costumes, mais especificamente, da sala de jantar da classe média, ele o faz com um certo ar de superioridade, ironicamente explícito, diga-se de passagem:

E através dos anos foram se aperfeiçoando os rituais e também os preconceitos. O interessante é que ninguém se arrepia com a mesa pobre. Muito pelo contrário. Há uma nostalgia da pobreza, do fogão de lenha, da cozinha preta de picumã, da janela pequena com a bilha de água, do bolo de fubá posto diretamente sobre a mesa. Confrontados com os costumes da classe média, nós, os grandes nobres, costumamos implicar. Cada um tem sua ojeriza particular, aguda, crônica, especialíssima.

Chegar em casa e encontrar a mesa posta desde as três da tarde, pratos e copos emborcados artisticamente, a salada sufocada por um filme de plástico ou guardanapo de papel... Dá uma ideia de pobreza micha que mata, uma depressão que Prozac nenhum levanta.

Feio mesmo, e quase uma unanimidade, são as comidas dentro da embalagem. [...]

Ninguém quer uma mesa de A época da inocência, mas talheres e vasilhas de inox podem estragar o jantar. ${ }^{273}$

272 HORTA, N. Ai, que implicância! In.: HORTA, N. Não é sopa: crônicas e receitas de comida. São Paulo: Companhia das Letras, 1995. p. 327-329.

273 Ibid., 1995 p. 47-48, grifo do autor. 
A narradora, desde o título, faz questão de explicitar que sua crítica aos costumes da classe média é de cunho pessoal, trata-se de uma implicância. Quer, talvez, com este jogo aberto, cooptar a simpatia do leitor para a sua causa, inconsciente ou conscientemente, aplicando a regra de Frye, segundo a qual a sátira eficaz requer que autor e leitor estejam de acordo sobre a coisa criticada, tornando-se contraproducente quando se baseia em esnobismo, preconceito e aversões pessoais ${ }^{274}$.

Quando ela diz, por exemplo, que ninguém se arrepia com a mesa pobre, é como se ela estivesse explicando que não é a pobreza de recursos que está sendo criticada, mas a pobreza de estilo, com sua mesa eterna ou parcialmente posta, sua toalha de plástico e sua comida servida nas próprias embalagens.

Só que a mesa pobre que ela descreve de pobre não tem nada, ao contrário, com seu fogão de lenha e seu bolo de fubá emborcado na mesa, ela tem a rusticidade opulenta ou a opulência rústica das cozinhas das memórias de Pedro Nava.

E, por outro lado, a qualificação de pobreza micha atribuída à mesa pré-posta soa esnobe, porque isso, muitas vezes, é decorrente não da falta de gosto, mas da falta de tempo, principalmente das mulheres que trabalham fora e dentro de casa, tendo que deixar as coisas já semiprontas para "adiantar o expediente".

A menção à obra A época da inocência, livro de Edith Wharton, depois filmado por Martin Scorcese, não deve ter sido por acaso. Wharton também implicava com a perda de estilo nos modos à mesa e na condução do lar, desde que as mulheres se tornaram, segundo ela, "o monstruoso regimento de emancipadas" e trocaram a complexa arte da vida civilizada por um diploma universitário ${ }^{275}$.

Não se está querendo dizer, contudo, que Nina Horta seja contra a emancipação feminina e a dona-de-casa-que-trabalha (sendo ela mesma um exemplar da classe), nem que os costumes de qualquer grupo, por mais trabalhadores que sejam, devam estar a salvo do

274 FRYE, 1973, p. 220.

275 WHARTON, E. A backward glance. New York: Touchstone, 1998. p. 60. 
humor. O problema aqui é que o modo-de-fazer da receita de sátira não foi executado como deveria.

\section{Patricya Travassos, A camaleoa}

É conhecida a ideia de Bergson de que o cômico está associado a uma certa rigidez no caráter e no espírito e ao automatismo nas ações e que o riso seria o seu castigo ${ }^{276}$.

Em um dos exemplos que usa para depreender sua hipótese, Bergson ${ }^{277}$ descreve o que ele chama uma "farsa de gabinete": um funcionário cuida de seus afazeres com regularidade matemática e não percebe que os objetos foram trocados por algum zombeteiro. Vai molhar a pena no tinteiro e lá encontra lama, vai sentar na cadeira e cai no chão; age no vazio, por força do hábito. O que há de risível nisso, segundo Bergson, "é certa rigidez mecânica quando seria de esperar a maleabilidade atenta e a flexibilidade vívida de uma pessoa". ${ }^{278}$

É curioso que a "maleabilidade atenta" e a "flexibilidade vívida", atributos tão louváveis para o homem bergsoniano, sejam características engraçadas nas mulheres. Talvez porque a tal maleabilidade feminina aconteça em função do desejo do outro. A capacidade da mulher de se adaptar ao estilo de vida do namorado da vez é um dos temas de Patricya Travassos 279 , em A camaleoa:

Maria Fernanda é assim. Criativa, antenada, contemporânea, mas insegura e carente até a alma: em vez de acreditar em suas enormes possibilidades criativas, absorve o universo do namorado do momento. Com Ricardo, virou fotógrafa e passou a ver o mundo pelo buraquinho de uma máquina fotográfica. Só pensava em luz, filtro, lente e enquadramento.

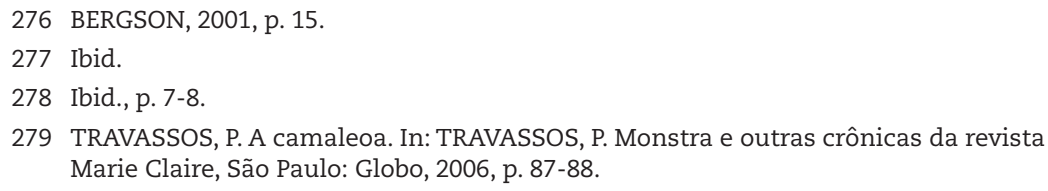


Mudou o guarda-roupa e vestia-se invariavelmente com uma calça cargo e um colete repleto de filmes. Passava horas em estúdios, jogando a luz e o brilho do seu talento pessoal no trabalho do namorado. [...] depois ela encontrou Billy, o guitarrista, a paixão da vez. Passou a ser a Yoko Ono da banda de rock. Fazia letras de música, cenários, bolava performances, videoclipes e viajava pelo Brasil. Como roqueira, exagerava nos casacos de couro, no jeans rasgado e na atitude sexo, drogas \& rock'n'roll. [...] [Depois] conheceu Rodolfo, o professor de filosofia, com quem começou sua fase acadêmica. Parou de se maquiar, malhar, consumir, e até óculos passou a usar. Investiu meses a fio em Platão, Sócrates e Nietzsche. Virou noites sem sexo e sem rock'n'roll, mas com muito, mas muito papo-cabeça.

Essa compulsão camaleônica é também observada por Leila Ferreira em personalidades "da vida real":

A escritora Gisela Rao também teve sua fase de mimetismo, em que nada dava certo. 'Meu ex-marido era um verdadeiro peixe', conta, 'e eu detesto água. Sinto frio e morro de medo. Mesmo assim, fui fazer um curso de mergulho. Foi um fracasso, que terminou quando eu caí em cima de uma estrela-do-mar e a destruí. Nunca mais mergulhei. Depois tive um namorado policial e eu, que sou toda Gandhi e Madre Teresa, me matriculei em um curso de tiro. Mais um fracasso.' Carol foi mais longe que Gisela na sua tentativa de agradar ao parceiro: 'Eu fui parar em Cuba, pra fazer um curso de cinema que meu ex-namorado queria, mas não podia fazer, por razões financeiras. O sonho era dele, não meu, mas ele me convenceu e eu fiquei lá dois meses. Depois, esse mesmo namorado fez uma tese de mestrado sobre o Brecht. Como eu achava que ele era muito mais inteligente e mais culto do que eu, comecei a estudar e a pesquisar com ele, pra conseguir acompanhar as conversas. No fim, eu sabia tudo sobre Brecht. Acho que seria capaz de defender a tese do meu namorado numa boa'. ${ }^{280}$

280 FERREIRA, 2007, p. 216-217. 
Observe-se que uma certa dose de identificação e de absorção do universo do outro faz parte do enamoramento e dos relacionamentos, mas isto por si só não seria necessariamente engraçado. O cômico talvez esteja no exagero da representação do modo como a personagem passa a agir como um espelho do parceiro.

Essa tendência a mimetizar o comportamento do companheiro talvez seja uma variante do papel de "espelho" que algumas mulheres costumam exercer e que Virginia Woolf observa em seu livro A room of one's own:

Ao longo dos séculos, as mulheres têm servido de espelhos, dotados do maravilhoso e delicioso poder de refletir a figura do homem com o dobro do seu tamanho natural. Sem esse poder, a Terra ainda estaria imersa em selva e pântano [...] Não importa qual seja o seu uso nas sociedades civilizadas, o espelho é essencial para toda ação heróica e violenta. Essa é a razão pela qual Napoleão e Mussolini insistem tão enfaticamente na inferioridade da mulher, pois sem essa inferioridade eles deixariam de engrandecer-se [...] E serve para explicar o quanto eles se inquietam ante a crítica que ela lhes faz. E o quanto é difícil para ela dizer ao homem que o livro dele não é bom, que o seu quadro é ruim ou seja lá o que for sem causar-lhe mais dor e raiva do que causaria se fosse outro homem que o dissesse. É que se ela começar a falar a verdade, a imagem dele no espelho encolhe, sua aptidão para a vida diminui. ${ }^{281}$

\section{Clarice Lispector, A procura de uma dignidade}

Para Bergson 282 , a comédia é uma brincadeira que imita a vida. Ele formula os procedimentos do vaudeville, como a repetição, a inversão

281 WOOLF, [1957], p. 35-36, tradução nossa.

282 BERGSON, 2001. 
e a interferência de séries, a partir dos jogos infantis, entre os quais se destacou o fantoche e seus cordões.

A ideia do fantoche aplicado à comédia é a do personagem que acredita ter controle dos seus atos, das suas palavras, do seu destino, os quais, na verdade, estão sendo manipulados por outrem. Ele é um joguete nas mãos de alguém que se diverte com isso ${ }^{283}$.

Apesar de sua inspiração lúdica, nunca é demais lembrar que esses mesmos procedimentos podem ser utilizados em prol do trágico e não do humor, dependendo do tipo de afeto que se deseja suscitar no receptor; se compaixão, riso ou ambos. No conto A procura de uma dignidade, de Clarice Lispector, por exemplo, eles são utilizados para suscitar sentimentos ambivalentes entre a compaixão e a derrisão diante dos equívocos de uma mulher de 70 anos que permanece infantil em relação a seu desejo e seu destino. O conto inicia-se com a sra. Jorge B. Xavier perdida no estádio do Maracanã. E a pergunta que acorre ao leitor coincide com aquela que um anônimo personagem faz a tal senhora: "Então, o que é que a senhora está fazendo aqui?" "Ela quis explicar que sua vida era assim mesmo, mas nem sequer sabia o que queria dizer com 'assim mesmo' nem com 'sua vida', nada respondeu". ${ }^{284}$

No decorrer do conto, descobre-se a razão do engano: ela deveria estar numa conferência perto do estádio, mas, por ser muito avoada e só ouvir as coisas pela metade, achou que conferência seria no próprio Maracanã e acabou perdida. O episódio deixa entrever que foi de modo avoado e distraído que a sra. Jorge B. Xavier viveu os 70 anos de sua vida. Descrita dessa forma, a personagem e sua vida desfocada parecem dignas mais de pena do que de derrisão, mas o conto é conduzido de modo a suscitar ambos e até mesmo indignação diante do alheamento de si que essa senhora demonstra.

A decisão da narradora de não dar à personagem um nome indica que dela se vai manter uma certa distância, além disso o fato de ela ser chamada pelo nome do marido indica uma posição

283 Ibid.p. 57-58.

284 LISPECTOR, C. A procura de uma dignidade. In: LISPECTOR, C. Onde estiveste de noite. Rio de Janeiro: Nova Fronteira, 1980. p. 10. 
complementar, a de quem não tem uma vida própria, como mostra o trecho em que, depois de ter feito uma compra, ela se vê na rua sem ter o que fazer. "Pois o Sr. Jorge B. Xavier viajara para São Paulo no dia anterior e só voltaria no dia seguinte"285. A única coisa de própria que a personagem parece, a contragosto, ter é o que ela chama de "aquilo":

Mas tudo o que lhe acontecera ainda era preferivel a sentir 'aquilo'. E aquilo veio com seus longos corredores sem saída. 'Aquilo', agora sem nenhum pudor, era a fome dolorosa de suas entranhas, fome de ser possuída pelo inalcançável ídolo de televisão. Não perdia um só programa dele. Então, já que não pudera se impedir de pensar nele, o jeito era deixar-se pensar e relembrar o rosto de menina-moça de Roberto Carlos, meu amor. ${ }^{286}$

Criada a distância estratégica da personagem, a impressão que se tem é que o narrador se compraz em fazer da sra. Jorge B. Xavier uma espécie de fantoche que ele manipula com seus cordões, fazendo-a assumir desejos e posturas francamente desfavoráveis. A uma certa altura, procurando por uma letra de câmbio, assunto do qual ela "pouco entendia", ela decide buscá-la debaixo da cama e percebe que estava de quatro:

Assim ficou um tempo, talvez meditativa, talvez não. Quem sabe, a Sra. Xavier estivesse cansada de ser um ente humano. Estava sendo uma cadela de quatro. Sem nobreza nenhuma. Perdida a altivez última. De quatro, um pouco pensativa talvez. Mas embaixo da cama só havia poeira. ${ }^{287}$

O comentário final sugere que a personagem é alheada como pessoa, pois é incapaz de reger a própria vida, e mesmo como uma

285 LISPECTOR, 1980, p.15.

286 Ibid., p.16.

287 Ibid., p. 15 
dona-de-casa, pois não dá conta dos documentos do marido nem tampouco supervisiona a limpeza da casa.

A suspeita de que o narrador está jogando de maneira cruel com a personagem é corroborada por algumas passagens, como esta quando ela ainda está perdida no Maracanã, e a descrição dos corredores lembra não apenas um labirinto, mas a ideia de uma caixa dentro de outra caixa dentro de outra caixa:

Então a senhora seguiu por um corredor sombrio. Este a levou igualmente a outro mais sombrio. Pareceu-lhe que o teto dos subterrâneos eram baixos. E aí este corredor a levou a outro que a levou por sua vez a outro. Dobrou o corredor deserto. E aí caiu em outra esquina. Que a levou a outro corredor que desembocou em outra esquina. ${ }^{288}$

A ideia de que se está brincando com o destino da personagem se torna mais evidente em outra passagem: "E de fato de muito longe ambos os viram. Mas um segundo depois tornaram a desaparecer. Parecia um fogo infantil onde gargalhadas amordaçadas riam da Sra. Jorge B. Xavier". ${ }^{289}$

Há uma série de outras circunstâncias nas quais a sra. Xavier se vê envolvida que exemplificariam ainda essa ideia de que ela não passa de um joguete nas mãos de outrem, porém a mais cruel de todas talvez seja a de colocá-la diante de si mesma na frente do espelho:

Mas, quem sabe? Se desistisse de Roberto Carlos, então é que as coisas entre ele e ela aconteceriam. A Sra. Xavier meditou um pouco sobre o assunto. Então espertamente fingiu que desistia de Roberto Carlos. Mas bem sabia que a desistência mágica só dava resultados positivos quando era real, e não apenas um truque como modo de conseguir. A realidade exigia muito da senhora. Examinou-se ao espelho para ver se o rosto se tornaria bestial sob a influência de

288 LISPECTOR, 1980, p. 7-8.

289 Ibid, p. 9. 
seus sentimentos. Mas era um rosto quieto que já deixara há muito de representar o que sentia. Aliás, seu rosto nunca exprimira senão boa educação. E agora era apenas a máscara de uma mulher de 70 anos. Então sua cara levemente maquilada pareceu-lhe a de um palhaço. A senhora forçou sem vontade um sorriso para ver se melhorava. Não melhorou. ${ }^{290}$

Comentários laconicamente mordazes, como esse último, se repetem ao longo do texto e funcionam como uma espécie de obstáculo a qualquer porta de saída que a personagem encurralada esperava ter encontrado, como se o narrador tivesse tripudiando da sua procura, sem rumo e sem vontade, de uma dignidade qualquer. A narrativa é um exemplo de um tipo de humor bem diferente daquele de Lygia Fagundes Telles, que mostra situações reversíveis e/ou inofensivas, dos quais se sorri com simpatia e leveza. No conto de Clarice, os comentários sarcásticos provocam uma espécie de "esgar sardônico", ri-se a contragosto dessa velhice sem saída, sem alento e sem redenção. Tal desalento seria trágico se o narrador assim o quisesse, mas, pelo que se infere do seu comentário final, prefere tratá-lo pelo viés da mordacidade: "Então pensou o seguinte: que ela forçaria o 'destino' e teria um destino maior. Com força de vontade se consegue tudo, pensou sem a menor convicção". ${ }^{291}$

Isso é aqui particularmente interessante porque mostra a quebra da "regra do humor humanitário", cujo lema é evitar rir de pessoas em situações dolorosas e embaraçosas, principalmente, se elas são irreversíveis ${ }^{292}$, atribuída ao tipo de humor que as mulheres fazem.

290 LISPECTOR, 1980, p. 17.

291 Ibid., p.16.

292 Cf. BARRECA, 1996, p.13-14. 


\section{Riem dos próprios corpos}

Leila Ferreira, Mulheres: por que será que elas se olham com lupa?

Propp afirma que o cômico está sempre ligado à esfera espiritual da vida humana, mesmo quando se pensa que esta comicidade é decorrente do seu aspecto físico, como uma calvície, por exemplo. Após uma série de afirmações um tanto contraditórias, ele conclui que a comicidade não estaria nem na natureza física nem na natureza espiritual do homem, mas numa correlação das duas, ali onde a natureza põe a nu os defeitos da vida espiritual ${ }^{293}$. Trata-se de uma ideia semelhante à de Bergson, quando este diz que fealdade cômica de um rosto expressa-se num esgar único e definitivo, como se toda a vida moral da pessoa nela estivesse cristalizada ${ }^{294}$.

Propp ${ }^{295}$ e Bergson ${ }^{296}$ advogam a ideia de que o riso é a punição da natureza por um defeito qualquer oculto ao homem, não sendo assim, portanto, um fenômeno da alçada da estética pura, mas voltado para um objetivo útil de aperfeiçoamento geral. Ao associar a deformação física cômica à manifestação de um defeito espiritual, Propp e Bergson sugerem que os feios não apenas são culpados (espiritualmente) pela própria fealdade, mas também merecem ser ridicularizados para se aperfeiçoar.

Menos eugênica é a proposta de Critchley no sentido de ver como inevitável "o conflito que existe entre ser um corpo e ter um corpo", e que é exatamente este conflito entre os aspectos físicos e "metafísicos" de ser humano que o humor explora. O risível estaria no retorno do físico sobre o metafísico, quando a pretensa sublimação trágica do humano derrapa no cômico ${ }^{297}$.

293 PROPP, 1992, p. 45-52.

294 BERGSON, 2001, p. 18.

295 PROPP, op. cit., p.44.

296 BERGSON, op. cit., p. 15.

297 CRITCHLEY, 2002, p. 43. 
Ainda que menos aperfeiçoadora e mais igualitária no sentido de que ninguém escapa ao conflito de ser e de ter um corpo, o cômico na teoria de Critchley apoia-se no conflito. Ou melhor, o conflito apoia-se, talvez, numa concepção que vê o corpo como um todo pronto e imutável. Tal concepção, segundo Bakhtin, a de um corpo único, individual e fechado, sem marca de dualidade, implica que todos os atos e acontecimentos que o afetam têm uma única direção: a morte não passa da morte, nunca coincide com o nascimento; a velhice distancia-se da juventude, todos eles só têm sentido e estão encerrados nos limites do nascimento e da morte individuais desse mesmo corpo, marcando o começo e o fim absolutos e não podendo jamais se reunir nele ${ }^{298}$. A esse corpo fechado, ele contrapõe o corpo grotesco:

O corpo grotesco é um corpo em movimento. Ele jamais está pronto nem acabado: está sempre em estado de construção, de criação, e ele mesmo constrói outro corpo; além disso, esse corpo absorve o mundo e é absorvido por ele.[...]

Por isso o papel essencial é entregue no corpo grotesco àquelas partes, e lugares onde se ultrapassa, atravessa os seus próprios limites, põe em campo um outro (ou segundo corpo): o ventre, o falo [...]. Todas essas excrescências e orifícios caracterizam-se pelo fato de que o lugar onde se ultrapassam as fronteiras entre dois corpos e entre o corpo e o mundo, onde se efetuam as trocas e as orientações recíprocas; [...] em todos os acontecimentos do drama corporal, o começo e o fim da vida são indissoluvelmente imbricados. ${ }^{299}$

Nessa concepção, a noção de "deformação corporal cristalizada e risível" de Propp e Bergson perde o sentido, pois o corpo grotesco não é estável, ele está sujeito a um incessante movimentar-se. Se antes, presume-se, essa concepção de corpo era particularmente adequada ao corpo feminino não apenas pela sua capacidade de acoplar-se ao corpo masculino, pela capacidade de gestação e aleitamento, mas

298 BAKHTIN, 1987, p. 281.

299 Ibid., p. 277. 
também por ter sempre tentado amoldar-se aos diferentes modelos de corpo vigentes a cada época, hoje, a mutabilidade dos corpos em busca de tornar-se o corpo ideal ou de apagar os efeitos da velhice tornou-se a norma. "Grotesco" hoje seria o conformar-se com a própria aparência, caso ela fuja aos padrões correntes do que é correto para narizes, cabelos, seios e barrigas, como comenta Leila Ferreira:

Antigamente, as mulheres comparavam-se com as amigas, as primas, as vizinhas. Vivíamos em um círculo restrito. Hoje temos como referência as atrizes, as cantoras, as modelos, as mulheres impecáveis das revistas. Somos bombardeadas com esses seres quase perfeitos e com a mensagem de que a perfeição existe. Basta querer, basta esforçar-se, basta dedicar-se (e consumir, claro) que qualquer uma de nós pode parecer-se com a celebridade preferida. Malhamos, compramos, passamos fome, levamos surra de toalhas e vamos nos esquecendo, cada vez mais, de que uma coisa é o corpo ideal e outra é o corpo possível. Antes, bastava emagrecer. Agora é preciso endurecer: temos que ter corpos rijos, definidos. No começo, olhar o ponteiro da balança era suficiente. Agora, além do peso, temos que saber qual é nosso índice de massa corporal. Nunca entendi o que é isso. E não quero entender. Aliás, faço questão de que coloquem no meu epitáfio que morri sem saber o que é índice de massa corporal. ${ }^{300}$

Propp ${ }^{301}$ denomina o exagero cômico como a ampliação de um defeito através da caricatura, da hipérbole e do grotesco. A caricatura põe em evidência um pormenor em detrimento do todo, enquanto a hipérbole exagera o todo e ignora o detalhe. No que tange às mulheres, o exagero dos próprios defeitos, a autodepreciação, é um recurso apontado, em muitos estudos, como característico da maneira como elas fazem humor ${ }^{302}$. Elas costumam buscar e enfatizar os próprios defeitos, olhando-os com uma lupa, como observa Leila Ferreira:

300 FERREIRA, 2007, p. 152-153.

301 PROPP, 1992.

302 Cf. BARRECA 1991. p. 1-37. 
Do pescoço de galinha às pernas de leitoa, passando pelo bumbum articulado, as mulheres têm sido implacáveis com elas próprias. Ampliamos nossos defeitos, inventamos defeitos que não existem e, além disso, usamos um vocabulário para nos descrever que não destinaríamos a nosso maior inimigo. 'Estou uma bruxa hoje', dizemos com naturalidade. 'Comi feito uma vaca', 'estou um elefante de gorda', 'estou a cara do bonequinho da Michelin, com esse tanto de pneus', 'olha que lixo que está meu cabelo', 'estou acabadaça [...]', 'minha pele está detonada', 'eu embagulhei depois dos quarenta', 'minhas coxas estão parecendo a superfície de Marte, de tanta celulite.' É com essa delicadeza que nos referimos a nós próprias. ${ }^{303}$

Leila mostra ainda que essa mania de concentrar-se nos próprios defeitos, elegendo um deles como carma, obsessão, motivo de eterna antipatia, e referir-se a eles da forma mais desqualificadora possível não se resume à expressão verbal, muitas mulheres vão às vias de fato:

Vanessa não só se castiga verbalmente como se aplica punições físicas quando briga com sua aparência. Outro dia chegou à faculdade atrasada e não conseguia manobrar o carro para estacionar. Um colega ofereceu-se para ajudar e viu que Vanessa estava dura ao volante, custando para se movimentar. Morrendo de vergonha, ela foi obrigada a confessar que estava com gesso no abdome e em parte do tronco para perder medidas. O colega só acreditou quando viu e ela admitiu que faz isso de vez em quando. Deixa a esteticista não só "engessar" as gorduras localizadas, mas "bater" nelas com toalhas, depois, para estimular a circulação. Surra de toalhas e gesso no abdome - tudo em nome da beleza? Mais uma vez: foi a isso que deram o nome de emancipação feminina? ${ }^{304}$

303 FERREIRA, 2007., p. 152-153.

304 FERREIRA, 2007, p.152-153. 
A noção corriqueira que se tem de "ter senso de humor", no sentido de "saber rir de si mesmo", é o que dá o tom do humor dos textos de Leila Ferreira, no livro Mulheres: por que será que elas precisam de vinte e seis tipos de xampu[... ${ }^{305}$. Seus textos, como o título do seu livro já diz, revelam o que as mulheres são capazes de fazer em nome do cabelo impecável, do corpo perfeito e do amor eterno. O tom, contudo, não é de sátira; sua ironia, quando há, não é mordaz. Leila não parece querer mudar a realidade, nem sequer denunciar os possíveis engodos que a indústria de cosméticos impinge à insensatez feminina, como os parâmetros de beleza, retocados com photoshop e difundidos pela mídia, impossíveis de serem alcançados e/ou mantidos pela maioria das mulheres.

Talvez ela queira que as mulheres passem a ver o corpo, os cabelos e os parceiros sob uma perspectiva menos dramática. O seu tom mais bem humorado do que sarcástico talvez venha do fato de ela fazer questão de se incluir nesse universo. Embora o título do seu livro seja: Mulheres: por que será que elas...?, desde o primeiro texto, ela muda o pronome para nós, deixando claro que também está a bordo da nau das insensatas.

Também ela sofre com a celulite, implica com os pneuzinhos, disfarça as rugas e acorda num bad hair day. Por isso, ela discorre com conhecimento de causa sobre lavagem, secagem, tingimento, hidratação, toucas, rolinhos, escova japonesa, escova definitiva, escova progressiva, alisamento com laser, com chocolate, formol e queratina, luzes, reflexos, baby-liss. Além dos 26 tipos de xampu, condicionadores de enxágue ou do tipo leave-in, sprays, pomadas, soro reparador para as pontas, gel, musse modeladora, musse para volume, creme anti-frizz e máscara hidratante, entre outros produtos. Isso apenas para os cabelos.

Esse é um dos recursos do seu humor, a exposição da incongruência entre a lista ad infinitum de procedimentos, técnicas, produtos e tratamentos que as mulheres fazem, e a eventual solução nula que a maioria dos itens deste arsenal pode trazer.

305 FERREIRA, 2007, p. 22-29. 
Outro recurso do humor dos seus textos é destacar as qualificações que a mídia e a indústria de cosméticos atribuem aos cabelos, rugas e celulites: a celulite é "a grande vilã da beleza feminina", "a danada", "a famigerada", "a celulite é traiçoeira" ${ }^{306}$. Os cabelos são rebeldes, indisciplinados. As rugas são ingratas, as gordurinhas são inimigas, enfim, fenômenos fisiológicos impessoais são transformados em personagens de drama mexicano.

$\mathrm{Na}$ época em que este texto começou a ser escrito, encontrava-se anunciado em uma revista feminina um kit de produtos de beleza que contém: um stick perfumado, um esfoliante para o rosto e uma água benfeitora euforizante que hidrata a pele ${ }^{307}$. Já não basta ter uma pele esfoliada, hidratada, esticada, desenrugada; doravante, a pele da mulher contemporânea deve estar eufórica.

\section{Riem da própria vaidade}

\section{Eneida Moraes, Conversa de mulher}

O alogismo cômico, para Propp ${ }^{308}$, coincide com a estultice, com a falta de inteligência, com a incapacidade mais elementar de observar corretamente, de ligar causas e efeitos, que nos leva a dizer coisas absurdas e/ou realizar ações insensatas.

No caso das mulheres, um dos motivos que as leva a abandonar a razão e fazer coisas absurdas é a vaidade. Na crônica Conversa de mulher, de Eneida Moraes, ela faz uma reflexão sobre as vantagens e desvantagens do rejuvenescimento pela retirada das rugas através da cirurgia plástica, isso em 1957:

Essa coisa está ficando tão comum e obrigatória que daqui a cinco anos ouviremos uma mulher dizer que está com

306 REVISTA MARIE CLAIRE: São Paulo: Globo, 2008. ISSN 0104-8589.

307 Ibid., p. 13.

308 PROPP, 1992, p.107-114. 
hora marcada num médico: - 'Hoje vou fazer minha operação plástica' - como hoje diz que tem hora marcada no cabeleireiro ou no dentista. Tiraremos rugas como tiramos sobrancelhas ${ }^{309}$.

As vantagens óbvias do procedimento são o rejuvenescimento e a recuperação da beleza e da juventude perdidas, mas o custo pode ser a aquisição de um ar de perfeita imbecilidade. Além disso, pelo fato de se tratar de um tratamento caro, as diferenças de idade, a partir de então, ficariam restritas às classes trabalhadoras, impossibilitadas de bancar as despesas da intervenção.

As cogitações da narradora são uma invectiva contra os excessos da vaidade e, também, contra as injustiças da desigualdade social, mas o seu ataque e sua denúncia são leves, entremeados de humor. Essa mistura de humor e ataque, segundo Frye, são os ingredientes da sátira. Mas ele lembra que, para que a sátira seja eficaz, autor e leitor devem estar de acordo sobre a coisa indesejada, sob pena de a crítica tornar-se facilmente obsoleta quando se baseia em esnobismo, preconceito e aversões pessoais ${ }^{310}$.

Sob o ponto de vista dos ingredientes, pode-se dizer que o texto de Eneida é levemente satírico, já que, como um modo de garantir a concordância do leitor para com a sua causa, ela apela para argumentos mais "impessoais", como a opinião dos médicos sobre o risco da imbecilização, as coisas tão mais significativas que o dinheiro da cirurgia poderia comprar, a injustiça de que velhice passasse a ser mais um ônus da classe trabalhadora.

Ao final das conjecturas, porém, ela parece entender que o processo, apesar de eventuais perdas e danos, é inevitável, mas continua firme na sua posição contrária à ideia de trocar as inscrições do seu rosto por uma lisura desprovida de história.

Apesar de consciente da irreversibilidade do desejo de parar ou de reverter o tempo, a narradora não poderia imaginar, na década de

309 MORAIS, E. Conversas de mulher. . [S.1.], [200-?]. Disponível em: <www.releituras.com. br>. Acesso em 28 abr. 2007.

310 FRYE, 1973, p. 220. 
1950, a que ponto as coisas chegariam. Sendo assim é curioso fazer uma comparação desse texto com o de Leila Ferreira sobre as loucuras que as mulheres cometem em nome da beleza e da juventude.

\section{Leila Ferreira: Mulheres: por que será que elas...?}

Cena 1. Laura, uma estudante de vinte e poucos anos, decidiu numa terça-feira à noite que iria emagrecer dois quilos para ir a uma. festa no sábado. Passou quarta, quinta e sexta comendo só abacaxi. No sábado, em vez de à festa, foi para o hospital: a boca tinha virado uma afta só. Ninguém come tanto abacaxi impunemente.

Cena 2. Edna, que já deixou de ser estudante há algum tempo, queria, porque queria, estrear uma roupa de inverno numa noite que pedia no máximo um traje de meia-estação. Tomou uma dose generosa de Novalgina em gotas, calculando que, com isso, sua pressão cairia e ela não sentiria calor. Resultado: a pressão de fato baixou, mas foi muito além do esperado, e nossa amiga, que tinha planos de ir a uma festa, passou a noite em casa, comendo pitadas de sal.

Cena 3. Um grupo de quatro amigas partiu com entusiasmo para um spa, em uma cidade vizinha, que acabava de ser inaugurado. No segundo dia, o entusiasmo deu lugar à fome incontrolável. No terceiro, numa atitude de desespero, acabaram comendo parte de uma samambaia que decorava o spa. O problema é que a planta tinha sido borrifada com pesticida, as quatro passaram mal e tiveram que voltar às pressas para casa.

São três exemplos apenas do que tem sido o cotidiano das mulheres de hoje. Neste universo feminino - um planeta com lógica própria, não resta a menor dúvida - viver tem sido um exercício alternado de inteligência e seu oposto, uma convivência nada equilibrada de destempero e comedimento. Ou 
alguém acredita que uma dieta à base de abacaxi, Novalgina e samambaia é sinal de bom senso? ${ }^{311}$

A autora observa que executivas, acadêmicas, médicas, mulheres brilhantes e competentes nos mais diversos campos da atividade humana parecem perder todo o bom senso quando se trata de perder peso ou parecer mais bonita ou mais jovem. Ela compila, ao longo da história e das culturas, alguns dos desatinos que as mulheres cometeram em nome da vaidade, tais como usar veneno no corpo, perucas de mais de um metro de altura ou pele de rato no lugar das sobrancelhas. Ela esperava que, depois de todos os avanços pós-feminismo, extravagâncias como estas tivessem deixado de existir. Mas, ao que parece, as mulheres continuam capazes de fazer coisas ainda piores, porque, se os desvarios do passado eram cometidos por uma minoria, hoje isto é um fenômeno de massa imposto pela ditadura da beleza e da juventude.

\section{Riem de sua obsessão pelo amor}

A ênfase nas personagens obstrutoras é um dos modos de desenvolvimento da comédia, é o que faz, geralmente, a ironia cômica, a sátira, o realismo e os estudos de maneiras; o outro modo, característico da comédia shakespereana, por exemplo, privilegia as cenas de descobrimento e reconciliação. É no primeiro que se situa a comédia de Molière, cuja fórmula consiste em focar uma só personagem obstrutora, como um pai opressivo, um avarento, um misantropo, um hipócrita ou um hipocondríaco ${ }^{312}$. Nesse tipo de comédia, o herói em si mesmo costuma ser medíocre em suas virtudes e desinteressante. A comicidade se constrói em torno das personagens cômicas que obstruem ou auxiliam a ação do herói. Esses personagens seriam: os alazónes ou impostores, os eírones ou depreciadores de si mesmos, os

311 FERREIRA, 2007, p. 18-19.

312 FRYE, 1973, p. 167-168. 
bufões (bomolóchoi) e o rústico (agróikos) ou o campônio ${ }^{313}$. O que caracteriza o alazón, segundo ele, é a impostura, mais por auto engano do que por hipocrisia, e o que a torna absurda é uma obsessão, uma paixão predominante, uma espécie de sujeição ritual. Sua função na peça consiste em, obcecado por sua veneta, por sua ideia fixa, repetir a obsessão $0^{314}$.

Nas crônicas, textos e cartuns analisados, há uma recorrência de dois recursos de construção do personagem cômico: a obsessão e a autodepreciação. As obsessões femininas têm, entre seus focos principais, a vaidade, representada pela obtenção e/ou manutenção do corpo perfeito e da eterna juventude, e principalmente pelo amor, representado pela obtenção e/ou manutenção do homem perfeito, mesmo que ela não saiba exatamente o que isto significa.

"Mulheres que amam demais" é um tema tão recorrente na amostra das autoras revisitadas, que foi quase irresistível a tentação de compilar uma antologia na qual se articulassem humor e amor. Contudo, como uma coletânea com esse perfil poderia servir para ratificar algum possível estereótipo de que a mulher, mesmo quando fala com humor, só fala de amor, isso seria um desserviço ao objetivo deste trabalho que é de, alguma forma, contribuir para negar, e não confirmar, a ideia de que mulher escreve sobre isso, mas não sobre aquilo. Sendo assim, optou-se por dar à recorrência do tema o seu devido destaque, mas sem deixar de mencionar outros alvos do humor escrito por mulheres.

Entre os muitos textos relacionados ao assunto, três foram destacados: O búfalo, de Clarice Lispector ${ }^{315}$, Pomba enamorada, de Lygia Fagundes Telles ${ }^{316}$ e Mulheres que amam demais, de Patricya Travas$\operatorname{sos}^{317}$. Neles, com diferentes graus de complexidade e nuances de humor, representa-se o modo de agir dessas mulheres, decorrente

313 FRYE, p. 39-40.

314 Ibid., p. 167-173.

315 LISPECTOR, C. O búfalo. In: LISPECTOR, C. Laços de família. Rio de Janeiro: Rocco, 1998a. p. $126-135$.

316 TELLES, 1980.

317 TRAVASSOS, 2006. p. 43-46. 
da paixão obsessiva, do amor não correspondido ou da assimetria entre a maneira obcecada, sofrida, quase fanática de amar das mulheres versus a maneira distraída, casual, quase esportiva de amar dos homens.

Nos três, ora elaborada, ora esquematicamente, há uma tentativa ou uma tentação de ironizar, espicaçar, aconselhar, às vezes com amargor, às vezes com veneno, às vezes com ternura, a mulher que só sabe amar e amar demais. E, uma vez que é na desmedida que se encontra o problema, os textos procuram advertir, desconstruir ou exorcizar esse amor em demasia, porque ele se tornou um castigo, ou um obstáculo ou, simplesmente, "brega".

\section{Clarice Lispector, O búfalo}

Em O Búfalo, de Clarice Lispector, uma mulher, cansada de tanto amar, vai ao zoológico aprender com os bichos como se faz para odiar. Este conto trata da dificuldade da mulher em lidar com sentimentos como a raiva e a violência. Dificuldade a qual, muitas vezes, atribui-se o uso pouco frequente que ela faz do humor, já que este teria, entre os seus componentes, uma certa dose de agressividade, sátira e zombaria ${ }^{318}$.

A impressão que se tem é que o conto lida de maneira irônica com a questão, pois, se por um lado a personagem tem dificuldade em agredir, porque "não passava de uma delicada"319, pode-se perceber um certo humor cruel por parte da narradora, que parece se comprazer em espicaçar o ressentimento e o amargor da protagonista, guardados no seu peito “[...]que só sabia resignar-se, que só sabia suportar, só sabia pedir perdão, só sabia perdoar, que só aprendera a amar, a amar, a amar"320.

E todo esse amor, dedicado a alguém que não a quer, ela deseja transformar em ódio: "Eu te odeio', disse ela para um homem cujo

318 Cf. FINNEY, 1994; BARRECA, 1996; MINOIS, 2003.

319 LISPECTOR, 1998, p.132.

320 Ibid., p. 131. 
crime único era o de não amá-la. 'Eu te odeio', disse muito apressada. Mas não sabia sequer como se fazia” ${ }^{21}$.

Para conhecer o ódio, então, ela vai ao zoológico aprendê-lo com os animais. "Mas onde, onde encontrar o animal que lhe ensinasse a ter o seu próprio ódio? o ódio que lhe pertencia por direito mas que em dor ela não alcançava? onde aprender a odiar para não morrer de amor? E com quem?"322.

O traço de brincadeira cruel que se supõe acontecer entre a narradora e a personagem, ansiosa por começar suas lições de ódio, já se instaura no início do conto: "Mas era primavera. Até o leão lambeu a testa glabra da leoa" ${ }^{323}$.

Ignorante das coisas do ódio, a personagem, num método empírico de aprendizagem, segue caminhando de jaula em jaula em busca de sua violência perdida. Numa série de ironias, iniciada com o fato de tudo se passar na primavera, a pior estação para quem quer experimentar o ódio, a narrativa se detém na descrição da inadequação de cada animal para os propósitos sangrentos da mulher: os leões estão em pleno acasalamento, a girafa é uma virgem airosa, o hipopótamo não passa de um rolo de carne, o camelo é um tapete velho; alguns macacos saltitam, uma macaca está amamentando, um velho macaco cego e doente está postado de braços abertos. Diante de cada um deles, a personagem é levada a vivenciar o oposto do sentimento que está procurando.

Esse espicaçar do ressentimento e do rancor da mulher-que-precisa-odiar-para-não-morrer tem o seu ponto máximo quando, tendo já quase desistido de encontrar seu par, ela vai andar de montanha-russa. Ao ser precipitada no vazio, ela não consegue conter a alegria reflexa e, subitamente, ao perceber que está brincando contra a sua vontade, ela se dá conta, profundamente ofendida, que "faziam dela o que queriam"324.

322 Ibid., p. 131.

323 LISPECTOR,1998, p. 126.

324 LISPECTOR,1998, p. 129. 
A partir desse ponto, a narrativa muda de tom, acaba a brincadeira de tentativa e erro. É como se a têmpera da mulher e a sua promessa de ódio estivessem até então sendo testadas. A questão final lhe vem, então, da pergunta muda nos olhos de um quati, a quem ela responde "desviando os olhos, escondendo dele a sua missão mortal" ${ }^{225}$. Com a cabeça encostada nas grades da jaula do animal, ela tem a impressão de que ela é quem está presa, que "a jaula era sempre do lado onde ela estava" ${ }^{26}$. E ela renega esse lado, esse mundo, esse perdão: "Nunca o perdão, se aquela mulher perdoasse mais uma vez, uma vez que fosse, sua vida estaria perdida" ${ }^{327}$. E, em seguida, ela revela a verdadeira natureza desse perdão e desse ódio que ela tanto procura: "Imaginar que talvez nunca experimentasse o ódio de que sempre fora feito o seu perdão, fez seu coração gemer sem pudor, ela começou a andar tão depressa que parecia ter encontrado um súbito destino"328.

É quando ela, finalmente, encontra o búfalo. E deste encontro vem a revelação de que o ódio sempre estivera muito próximo, mas sem que ela o percebesse, como se, por estar tão misturado ao perdão, ele lhe fosse insípido, incolor, inodoro. Ela entende, então, que não veio ao zoológico buscar uma definição de ódio, mas a sensação do ódio. Isso coloca a questão da "dificuldade" da mulher com a agressividade numa perspectiva desconcertante e interessante. A dificuldade está não em saber o que o ódio é, mas em gozar dos seus prazeres.

Lygia Fagundes Telles, Pomba Enamorada ou uma história de amor

O conto é a história da paixão obsessiva e não correspondida de uma moça virgem, suburbana, ajudante de cabeleireiro, que se

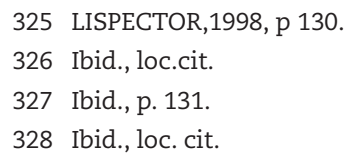


subscreve "Pomba Enamorada" nas cartas de amor que dedica a Antenor, o homem por quem ela é loucamente apaixonada, mas não é correspondida.

Esse é um conto "ótimo" no sentido que a fonologia dá a esta palavra quando diz que a sílaba tônica é o contexto ótimo para a depreensão de vogais. Pois assim é "Pomba Enamorada...", o contexto ótimo para se pensar a diferença tão volátil e espinhosa entre o "rir de" e o "rir com", através dos mecanismos de construção da personagem obsessiva.

Figura recorrente da comédia de costumes, a personagem cômica normalmente aparece em cena para obstruir os planos do herói, mas sua função principal consiste em, obcecada por sua veneta, por sua ideia fixa, repetir a obsessão ${ }^{329}$, tendo na comédia de Molière, talvez, seus representantes mais conhecidos, como o avarento, o hipocondríaco e o marido apavorado com a possibilidade de vir a ser corno.

Por razões já discutidas no capítulo 1, esse tipo de personagem costuma ser construído para ser alvo de derrisão. Para isso, é necessário neutralizar a empatia do receptor através da escolha deliberada dos traços mais idiossincraticamente antipáticos, rabugentos, pedantes de sua personalidade, e, de preferência, referir-se a ela de um modo que vai do desdenhoso ao francamente satírico. Deste modo, a plateia, em vez de se compadecer diante das desditas ou de se aterrorizar diante das consequências de falhas que são, afinal, levianas, superficiais, já que não acarretam morte ou perda considerável, ri e torce pela punição do ridículo ${ }^{330}$.

Sob o ponto de vista da ideia fixa, a obsessão de Pomba Enamorada por Antenor poderia fazer dela uma personagem cômica: a partir de um único encontro com esse homem num baile, ela é tomada pelo coup de foudre: "Encontrou-o pela primeira vez quando foi coroada princesa no Baile da Primavera e assim que o coração deu aquele tranco e o olho ficou cheio d'água, pensou: acho que vou amar ele pra sempre." ${ }^{331}$

329 FRYE,1973 p. 167-173.

330 MENDES, 2001. p.53-54.

331 TELLES, 1980, p. 90. 
E passa a persegui-lo implacavelmente, usando todos os recursos que são permitidos a uma moça virgem:

Ela foi à Igreja dos Enforcados, acendeu sete velas para as almas mais aflitas e começou a Novena Milagrosa em louvor de Santo Antônio, isso depois de telefonar várias vezes só pra ouvir a voz dele. Nesses dias de expectativa, escreveu-lhe catorze cartas, nove sob inspiração romântica e as demais, calcadas no livro Correspondência Erótica, de Glenda Edwin, que o Rôni lhe emprestou. Com recomendações, porque agora, querida, a barra é o sexo, se ele (que voz maravilhosa!) é Touro, você tem que dar logo, os de Touro falam muito na lua, nos barquinhos mas gostam mesmo é de trepar. Assinou Pomba Enamorada mas na hora de mandar as cartas, rasgou as eróticas, foram só as outras. ${ }^{332}$

Além das novenas e das cartas, ela compra presentes, tricota suéteres, faz mandinga, tenta o suicídio, trai o marido em pensamentos, tudo isto para ficar com um homem que lhe diz e repete que não está interessado, que ela procure outro:

Antes, falou bem dentro do seu ouvido que não o perseguisse mais porque já não estava aguentando, agradecia a camisa, o chaveirinho, os ovos de Páscoa e a caixa de lenços mas não queria namorar com ela porque estava namorando com outra, me tire da cabeça pelo amor de Deus, PELO AMOR DE DEUS! ${ }^{333}$

A obsessão, portanto, está aí, mas a personagem não se configura como cômica, o malogro de suas peripécias não leva à derrisão, como se houvesse, no nível da enunciação um movimento de aproximação e não de distanciamento da personagem. Esse gesto de aproximação se dá, curiosamente, pela quase indiferenciação entre a voz da narradora e as ações da Pomba Enamorada. A narrativa é na terceira

332 TELLES, 1980, p. 91.

333 Ibid., loc. cit. 
pessoa, mas é como se a narradora acompanhasse de muito perto os menores gestos da personagem, usando sua linguagem, suas expressões, compreendendo suas motivações, é quase como se a narradora mimetizasse a personagem. A partir desse gesto, o que se constrói não é o alvo do riso de superioridade diante da mulher "sem noção", que age contra as boas regras do relacionamento amoroso; ao contrário, o que se percebe é o encurtamento ou a neutralização da distância entre o espectador e a personagem, o que permite uma identificação com ela e o seu drama.

Embora se possa argumentar, com razão, que a personagem foi de certa forma punida pela sua insistência num sentimento não correspondido, inclusive com uma tentativa de suicídio, o seu amor eterno e incondicional parece não apenas despertar simpatia, mas também aprovação. No final do conto, apesar de todas as decepções e frustrações que o amor por Antenor lhe trouxe, a Pomba Enamorada não desiste da sua paixão e vai ao seu encontro com o que parece ser a bênção da narradora:

No noivado da sua caçula Maria Aparecida, só por brincadeira, pediu que uma cigana muito famosa no bairro deitasse as cartas e lesse seu futuro. A mulher embaralhou as cartas encardidas, espalhou tudo na mesa e avisou que se ela fosse no próximo domingo à estação rodoviária, veria chegar um homem que iria mudar por completo sua vida, olha ali o Rei de Paus com a Dama de Copas do lado esquerdo. Ele devia chegar num ônibus amarelo e vermelho, podia ver até como era, os cabelos grisalhos, costeleta. O nome começava por A, olha aqui o Ás de Espadas com a primeira letra do nome. Ela riu seu risinho torto (a falha do dente já preenchida, mas ficou o jeito) e disse que tudo isso era passado, que já estava ficando velha demais pra pensar nessas bobagens, mas no domingo marcado deixou a neta com a comadre, vestiu o vestido azul-turquesa das bodas de prata, deu uma espiada no horóscopo do dia (não podia ser melhor) e foi. ${ }^{334}$

334 TELLES, 1980. p.93. 


\section{Patricya Travassos, Mulheres que amam demais}

O tema das mulheres que amam demais ou que colocam todas as suas fichas e expectativas no relacionamento amoroso, como já se disse, é um tema recorrente na amostra de contos recolhidos. Recorrência que, por si só, já é um recurso da comédia, como se vê em Bergson $^{335}$, e que se torna ainda mais curiosa quando se analisam as diferentes circunstâncias de enunciação e se percebe que pouca coisa a esse respeito mudou, nas quase quatro décadas que separam Pomba Enamorada (1970) e Mulheres que amam demais (2006).

O texto de Patricya Travassos ${ }^{336}$ também é a história da obsessão de uma mulher apaixonada e de como essa obsessão se origina também de um quase nada: basta uma única dança num baile ou um "te ligo..." displicente para ligar a ignição da bola de neve da paixão feminina:

Pela milionésima vez Ana Luiza recapitulou as palavras ditas por Fernando Jorge quando se despediram naquele sábado à noite. Ele disse: 'Vou voltar de São Paulo na quinta-feira e te ligo[...]' '. A quinta-feira já estava terminando e nada. Durante toda a semana, Ana Luiza não tinha feito outra coisa a não ser se preparar para o displicente e descomprometido 'e te ligo'. Creditou todos os abdominais, exercícios para glúteo e aeróbico na esteira nessa relação que mal tinha começado, mas na qual depositava todas as fichas. Aliás, Ana Luiza depositava fichas e expectativas em qualquer homem que se aproximasse. "Caiu na rede é peixe" era a sua filosofia. ${ }^{337}$

O que mudou nas três ou mais décadas que separam os textos é que, antigamente, uma Pomba Enamorada podia passar anos a fio, a vida toda talvez, obcecada por um único homem; já uma Ana Luiza, de 2006, está obcecada por ter um homem, qualquer homem, para chamar de seu. Se não der certo com Fernando Jorge, "a fila anda”.

335 BERGSON, 2001. p. 25-27.

336 TRAVASSOS, 2006.

337 Ibid., p. 44. 
Enquanto Pomba faz promessa, tricota suéter e escreve cartas com pseudônimo, Ana Luiza malha, discute a relação e deixa mensagem na secretária eletrônica:

Ana Luiza faz parte do numeroso time que acredita que a vida de uma mulher só tem sentido ao lado de um homem. Mas sua sede de amor assusta qualquer um. Ela erra desde o início. É do tipo que discute a relação no primeiro encontro, telefona toda hora para o trabalho do cara, põe apelidos ridículos, faz carinho em excesso e logo introduz a família. Mas de tanto levar coice, bolo e fora, estava aprendendo a se controlar. ${ }^{338}$

Voltando à questão da diferença entre o cômico e o humor - sempre pensado mais como uma questão de grau do que de tudo ou nada -, a partir da construção da personagem, é possível pensar que Ana Luiza pende mais para o cômico, inclusive no sentido de ser uma personagem obstrutora dos seus próprios sonhos de construir um relacionamento estável:

Rasteja até o telefone e, desobedecendo a tudo o que a duras penas aprendeu, liga para Fernando Jorge. Atende a caixa postal dele, mas ela não se dá por vencida. Em vez de desligar, solta toda a tensão que a espera lhe provocou, numa avalanche descontrolada de carência. Chora ao telefone, faz juras de amor e implora por carinho. Mistura os nomes de todos os ex, chama ele de Zé Maurício, Augusto César, e finalmente de Fernando Jorge. E acaba aos prantos, soluçando no viva-voz sua má sorte com o sexo oposto, tendo Sting como trilha do dramalhão. ${ }^{339}$

Seu comportamento é absurdo porque solapa sistematicamente suas relações incipientes. As tintas sobre os seus vexames e seus "micos"

338 TRAVASSOS, 2006. loc. cit.

339 TRAVASSOS, 2006 , p. 45. 
são carregadas para torná-la alvo de uma certa derrisão, nos moldes de Bergson ${ }^{340}$, uma derrisão educativa para ver se ela aprende.

\section{Sônia Coutinho, Darling ou do amor em Copacabana}

Embora ainda dentro da temática dos relacionamentos amorosos, o texto de Sônia Coutinho se afasta do núcleo "mulheres-que-amam-demais". A narrativa gira em torno do relacionamento de uma semana entre a narradora, que deve ter entre quarenta e cinquenta anos, com um rapaz vinte anos mais novo, a quem ela se refere como darling. Pela referência a uma "calça de veludo brilhante e bata bordada com espelhinhos redondos" ${ }^{341}$, acredita-se que a história se passe nos anos 1970.

Uma das possibilidades de analisar a construção do humor desse conto é sob o viés dos clichês que compõem o relacionamento entre a-coroa-enxuta-e-o-gato-de-vinte-e-poucos-anos. Esta leitura é sugerida pelo próprio texto, onde se percebe o uso do hífen ou a inicial maiúscula para marcar a descrição de alguns elementos, como se eles fossem típicos de tais situações. É o caso, por exemplo, do pai de darling: "pai-médico-do-interior-que-manda-a-mesada-todo-mês"342; do Jovem Autor Teatral, que, ao falar dos participantes do seu grupo, os caracteriza como: "17-de-ambos-os-sexos-muito-jovens-e-lindos-já-dormi-com-todos"343; o apartamento de Darling: "apartamento-alugado-pela-família-para-os-filhos-estudarem-no-Rio"; as roupas dos personagens: "você com o Roupão de Seda vermelha que lhe dei para substituir o calção molhado, eu com a Túnica Indiana em Cima da Pele" ${ }^{344}$.

Os trechos que equivalem às falas dos personagens recebem o mesmo tratamento como se, por sua vez, fossem uma espécie de

340 Cf. BERGSON, 2001, , p. 15.

341 COUTINHO, S. Darling, ou do amor em Copacabana. In: COUTINHO, S. . Uma certa felicidade. 2. ed. Rio de Janeiro: Rocco, 1994. p. 62.

342 Ibid., p. 60.

343 Ibid., p. 63

344 COUTINHO, 1994, p. 60, grifo do autor. 
bordão do gênero: "Portanto o darling me beija e me acaricia, jurando um amor eterno: ficaremos-juntos-a-vida-inteira-não-importa-adiferença-de-idade-pois-meu-tio-casou-com-mulher-20-anos-maisvelha-e-os-dois-viveram-felizes-para-sempre." ${ }^{345}$

A construção do texto tendo como base o dejà-vu sugere que a narradora ou já viveu ou já "viu esse filme" vezes demais, sugestão que se intensifica com o trecho da narração de sua autobiografia:

\begin{abstract}
Vou ficando cada vez mais sentimental, é quando lhe conto o meu passado barroco/feérico/verdadeiro \& mentiroso: viúva de um campeão internacional de automobilismo, protegée de um diplomata grego aposentado, atriz de teatro e cantora de ópera, amante de um japonês, de um turco e um homossexual riquíssimo, que me presenteou um rubi indiano, antes de fugir para Hong-Kong com um trapezista louro, viajei por Europa e África, onde observei, numa verde/sumarenta planície marroquina ao entardecer, dromedários e flamingos cor-de-rosa correndo/voando. ${ }^{346}$
\end{abstract}

Talvez achando que tenha exagerado um pouco nos lances sensacionalísticos, ela acrescenta, ironicamente: "Mas já que a vida é cheia de altos e baixos, acabei datilógrafa em escritório, bati bolsinha na Lapa, agora me encontro ganhando a vida como representante/vendedora de produtos de beleza." ${ }^{347}$

Para darling, o final do conto reserva três finais possíveis e coerentes com a profusão de clichês que caracteriza o conto: empresário de um grupo de música pop, líder terrorista ou marido-da-virgem-que-engravidou-pra-casar. Mas a declaração final da narradora soa um tanto "superior" demais para quem vinha embalada em tantos lances folhetinescos: "eu nunca mais te verei, darling, mas como o fresco vento de maio desmancha as pegadas na areia da praia, depressa a passagem dos dias apaga a marca dos infortúnios

345 Ibid., p. 61.

346 Ibid, p. 61 grifo do autor.

347 Ibid., loc. cit. 
do amor em Copacabana"348. Faltou talvez dizer que ao fundo Dolores Duran cantava Fim de caso ou Dalva de Oliveira, Tudo acabado.

\section{Riem da falta}

Coisa sempre suscitadora de riso é o malogro da vontade humana ${ }^{349}$, quando o resultado é incruento obviamente (ou, pelo menos, assim se espera). Por ingenuidade ou distração do sujeito, por acidente ou qualquer outra razão, tudo sai diferente e geralmente pior do que havia sido previsto. No caso específico do cômico proveniente do malogro físico, como a queda, o escorregão, o sucesso de programas como As Videocacetadas, do Faustão, é uma prova do riso sádico que a miséria alheia provoca. No plano do humor, um dos maiores clássicos do gênero trata justamente das desventuras e trapalhadas de Dom Quixote. Normalmente isso é engraçado justamente porque visto de fora. O próprio sujeito do malogro não costuma achar muito engraçada a própria queda, a menos, é claro, que tenha senso de humor no sentido freudiano do termo, ilustrado pelo clássico caso do criminoso que, sendo levado à forca numa segunda-feira, comenta: "Bem, a semana está começando otimamente" 350 . Tal capacidade de rir das próprias desventuras, segundo o mesmo Freud, é um fenômeno difícil de ser encontrado ${ }^{351}$.

\section{Danuza Leão, É bom estar em casa}

A crônica de Danuza Leão, É bom estar em casa ${ }^{352}$, trata de um malogro em grande estilo. Tendo nas mãos todos os ingredientes para um jantar deslumbrante: Paris, um restaurante caríssimo, ostras, vinho

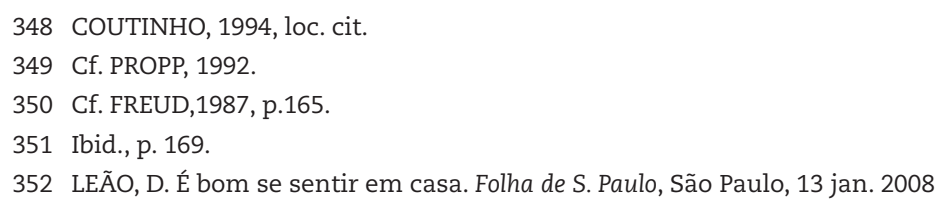


francês, três cartões de crédito, ela vê sua perspectiva de uma noite inteira dedicada aos prazeres gastronômicos se transformar em uma sucessão de fiascos: da escolha errada de ostras ao cigarro que já não pode mais fumar num bistrô francês.

Dois aspectos sobressaem nessa crônica. Um deles é a ironia entre a frase de abertura do texto "É bom estar só em Paris" e, logo em seguida, o lamento por não ter um homem do lado para escolher o vinho, o vinho que seria tomado para que ela não pensasse em mais nada, só nos prazeres do paladar:

É bom estar só em Paris - se é que alguém está realmente só em alguma cidade do mundo. E nessa noite fui fazer uma extravagância pensando que, afinal, eu mereço: jantar num restaurante caríssimo, só de coisas do mar.

$[\ldots]$

Mas na hora de escolher o vinho começa; ah, se estivesse com um homem do lado. A escolha de uma mulher, no quesito vinhos, é sempre posta em questão. Estou sozinha num restaurante chiquérrimo de Paris, com três cartões de crédito na carteira e morta de medo do maítre e dos garçons - tem sentido? 353

Isso parece uma confissão de que o que precisa ser realmente esquecido é o fato de estar só em Paris, este parece ser o motivo que fará malograr o projeto do jantar. Este que seria uma compensação pelo fato de a narradora estar só em Paris transforma-se em um fiasco justamente pela ausência desse homem para fazer as escolhas corretas e acaba por expor o seu desamparo - logo ela, confessadamente vivida e experiente - diante do maître, do garçom e do complicado ritual que é a escolha do vinho e das ostras num restaurante francês.

Porém mais curioso do que o teor da "confissão" é a própria "confissão" em si. Por que contar o fiasco? Por que expor as próprias desventuras às diversas, e, talvez derrisórias, interpretações alheias? Freud diria que, nesse tipo de situação, o que se espera 
do desventurado é que ele expresse sua zanga, suas queixas, seu sofrimento; e o receptor, então, prepara-se para evocar as mesmas emoções em si mesmo. Esta expectativa, no entanto, é frustrada, quando o desventurado - ou a desventurada, no caso - usa o humor e, em vez de expressar sentimentos, faz um gracejo. Nesse caso, "o gasto de sentimento, que é assim economizado, transforma-se em prazer humorístico no ouvinte"354.

Talvez uma outra versão para a explicação de Freud esteja no final do romance Heartburn, de Nora Ephron. Nele, a protagonista Rachel acaba de perder o marido para uma outra mulher, e quando uma amiga lhe pergunta por que ela sempre acha que precisa "transformar tudo em uma história", Rachel responde:

Porque se eu conto a história, eu controlo a versão. Porque se eu conto a história, eu posso fazer você rir, e eu prefiro que você ria do que tenha pena de mim. Porque se eu conto a história, ela não dói tanto. Porque se eu conto a história, eu posso seguir em frente. ${ }^{355}$

\section{Riem da língua $a^{356}$}

O terceiro elemento da tríade do risível, segundo Aristóteles ${ }^{357}$, são as palavras ou, como quer Propp, os instrumentos linguísticos da comicidade. Este afirma que a língua não é cômica por si só, mas sim porque reflete alguns traços da vida espiritual de quem fala, a sua falta de lógica ou a imperfeição de seu raciocínio ${ }^{358}$. O primeiro problema aqui é definir o que é significa ser cômico (ou qualquer outra coisa) "por si só", fora de algum tipo de contexto ou de um

354 FREUD, 1987, p. 166.

355 EPHRON, N. Heartburn, New York: Vintage Books, 1983. p. 176-178. Traducão nossa.

356 Cf. PROPP, 1992.

357 ARISTÓTELES, 2005, p. 74

358 PROPP, op. cit., p.119. 
sistema de relações. Mas supondo que ele queira dizer que a "língua por si só" seja a língua enquanto "conjunto de signos e sua regras de articulação", ainda assim ele estaria discordando, pelo menos, de Freud ${ }^{359}$ e de Millôr ${ }^{360}$, quanto à possibilidade de se rir do código “em si" e não de quem o está usando. Nos dois textos escolhidos para exemplificar o tema, O convite, de Cleise Mendes ${ }^{361}$, e Sabiás e rouxinóis, de Vera Pacheco Jordão ${ }^{362}$, acredita-se que é sobre a língua que o humor recai.

\section{Cleise Mendes, O convite}

Em O convite, uma noiva, com todos os preparativos do casamento em andamento - juras trocadas, lençóis bordados e presentes recebidos -, senta-se para escrever o convite e depara-se com a laboriosa tarefa de escolher a palavra ideal, aquela que melhor traduzisse o conjunto de ritos que ela está prestes a protagonizar. Mais do que trabalhoso, o artifício de fazer coincidir a palavra, que ela tenta escolher, com o ato do qual ela vai participar, revela-se impraticável para Lívia e ela, por fim, dá-se conta da impossibilidade de realizar quaisquer dos dois atos: a escrita e a cerimônia.

Uma das possibilidades de pensar o humor do conto é sugerida pelo trecho que mostra que a protagonista, quando criança, já se havia dado conta das possibilidades de armar e desarmar a língua, como se ela fosse um brinquedo:

Tudo começou lá pelos dez anos, quando um texto didático, entre ilustrações e tudo, explicitava os vários sentidos de "folha", e Lívia sentiu que era sentido demais, não dava depois pra retomar, e ficou enganchada no mistério líquido desse

359 FREUD, 1996.

360 FERNANDES, 2002, p. 594-597.

361 MENDES, C. A terceira manhã. Rio de Janeiro: Imago; Salvador: Fundação Cultural do Estado da Bahia, 2003. p. 43-44. (Bahia: Prosa e Poesia).

362 JORDÃO, V. P. Sabiás e rouxinóis. In: MAGALHÃES JUNIOR, R. Antologia de humorismo e sátira. Rio de Janeiro: Bloch, 1969. p. 422-426. 
lh que só podia ser coisa de mergulho, de língua molhada, e nunca a secura branca do papel. Tomou ódio do livro explícito, obsceno, mas depois aprendeu a imitá-lo, furtivamente, para consumo próprio e solitário, armando e desarmando sílabas como peças de ligue-ligue, castelos, caixinhas, construindo, destruindo, pequena deusa. ${ }^{363}$

Tais possibilidades lúdicas sugeridas no texto remetem a Bergson e a sua associação dos princípios do humor ao mecanismo de alguns brinquedos infantis ${ }^{364}$, principalmente, neste caso, a caixa de surpresas, na qual o boneco de mola não se cansa de pular para cima a cada abrir e fechar da tampa: "Lívia conhecia desde a infância esses alçapões. Estranhara coisas como cadeira, porta, luva, mamãe. E sabia que repeti-las era a danação. Saltavam, desgovernadas, mais e mais ficavam vivas." 365

E, também, a bola de neve em que uma pequena causa provoca uma reação em cadeia, cujas consequências fogem ao controle, sendo muito maiores do que o fator inicial que as originou:

Foi aí. A palavra cresceu, inflou, torceu-se, desgarrada. Lívia tentou retê-Ia, como se a tivesse tido, alguma vez, dócil, doméstica. Tentou prendê-Ia em fragmentos cristalizados: cerimônia de batismo, de encerramento, de posse, a cerimônia terá lugar, após a cerimônia, no decorrer da ceri ... Tolo truque. Que a repetição ilude, trai. Mais imensa, a palavra. ${ }^{366}$

O que Lívia parece perceber ao sentar para escrever o próprio convite de casamento é que, na infância, o brincar com as palavras - repetindo-as, desmontando-as, estranhando-as - fazia com que as palavras, qualquer palavra, correspondesse a um "abre-te, Sésamo" que dava passagem, se não para uma outra dimensão, pelo menos para

363 MENDES, 2003, p. 43.44 loc. cit.

364 BERGSON, 2001, p. 50-58.

365 MENDES, 2003, p. 44.

366 Ibid., loc. cit. 
outras inúmeras possibilidades. Ao escrever "cerimônia" no papel, ela inadvertidamente insere a senha que acessa o velho jogo infantil, ela reabre a tampa da caixa, e a palavra, como se fosse o incansável boneco de mola, pula para fora e parece adquirir vida própria. Ao tentar reencaixotá-la em contextos seguros: "cerimônia de batismo", "de encerramento", “de posse”, esta repetição só faz a palavra saltar ainda mais forte. Como se, uma vez posto em ação este jogo com as palavras, uma verdadeira reação em cadeia se deflagrasse, a bola de neve fosse crescendo e as consequências se tornassem muito maiores do que a pequena palavra que lhes deu origem. Como se o jogo que tanto a fascinava quando criança, agora às vésperas do casamento, parecesse assustador: "Lívia, portanto, criança, era sábia, e transformara em jogo essas aventuras de palavras sem rédea. Mas era assustador, agora. A gráfica não esperaria mais, a mãe ficaria aflita, e o noivo ia olhar para ela do modo que mais temia, em urgente desamparo." 367

A reação em cadeia que se põe em jogo à escrita da palavra "cerimônia”, e o conjunto de derivações, combinações e alusões desagradáveis que ela evoca -

A lembrança do noivo enchia essa urgência de perigosa ternura, mas a palavra desgarrada no papel derretia como cera, exalava como amônia, náusea de viagem sem retorno, de mergulho no poço. Cera e amônia. Amarga amônia. Acrimônia. Cerimônia. Cerimonial, cerimonioso, cerimoniosamente. Credo! Totalmente em órbita, girando louca cada sílaba, sem se encorpar [...] no corpo antigo. ${ }^{368}$

- parecem fazer com que Lívia se dê conta de que, se na infância a brincadeira de palavras lhe abria alçapões, como o de Alice, agora, a tarefa de escrever o convite do seu casamento assemelha-se a um "fecha-te, Sésamo": E ela acaba por preferir não casar a fazer o jogo da cerimônia:

367 MENDES, 2003, p. 45.

368 Ibid., loc. cit. 
Tinha que escrever agora, e cada palavra a escrever era para sempre. Breve as máquinas imprimiriam o que agora fosse dito, e o dito a faria entrar de branco pela porta alta, desmesurada, única, e atrás dela todas as outras portas se fechariam de vez. Definitivo. Infinitivo. Droga! ${ }^{369}$

Uma outra possibilidade de humor nesse texto é pelo viés da ironia no sentido que Linda Hutcheon define quando diz que todo texto literário é irônico por comportar inúmeras significações, por caber sempre o dito e o não dito, por estar sempre aberto à interpretação e suas delícias ${ }^{370}$. O conto mostra que não apenas o texto literário está aberto a essas possibilidades, mas qualquer texto, mesmo o mais prosaico conjunto de fórmulas cerimoniais, como um convite de casamento. É como se o lidar com as palavras, mesmo uma palavra tão conservadora, convencional, burocrática, ritualizada, como "cerimônia", sempre pudesse abrir os alçapões de possibilidades inesgotáveis de alusões, referências, significados e, como tal, fosse uma recusa à conversão e um convite ao jogo, ao humor, à diversão.

\section{Vera Pacheco Jordão, Sabiás e rouxinóis}

Outro texto escolhido para exemplificar o humor que tem como alvo a língua é o de Vera Pacheco Jordão ${ }^{371}$, Sabiá e rouxinóis. Ela inicia sua crônica relembrando um velho bordão ouvido na sua infância:

"Em Portugal canta o rouxinol e aqui no Brasil canta o sabiá, mas a distância entre cá e lá é tão grande que o que se canta cá não se ouve lá, e o que se canta lá não se ouve cá. Por isso é que ninguém sabe a história da casinha amarela que eu vou contar. Quer que eu conte?"

369 MENDES, 2003, p. 45

370 HUTCHEON, 2000. p. 78.

371 JORDÃO, 1969, p. 422-423. 
Glosando o mote de que o canto do rouxinol português difere daquele do sabiá brasileiro, ela desconstrói a ideia de uniformidade, que há quem suponha existir, entre a língua que se fala no Brasil e em Portugal. Ela diz que tendo viajado por quase toda a Europa sem maiores dificuldades linguísticas, só a muito custo se fez entender pelos lusitanos, não tanto pela pronúncia e sintaxe, mas principalmente pelas palavras do quotidiano, que são totalmente diferentes de um lugar para outro:

Assim foi que, perguntando ao porteiro do hotel em Lisboa se havia trem para a praia da Nazaré, o homem respondeu-me em tom de espanto:

- Trem não, minha Senhora, que é demasiado distante ... Que eu saiba, o trem foi inventado justamente para as grandes distâncias, mas não discuti:

- E ônibus?

- Ai, minha Sra., de ônibus V. Excia. levaria o dia todo para lá chegar. É preferível a camionete.

- Camionete ... (pensei num caminhão pequeno e fechado) mas não será muito incômodo?

E o diálogo continuou até que se esclarecesse o quiproquó: Em Portugal trem é carro puxado por cavalos, ônibus é o nosso trem vagaroso que chamamos leiteiro, camionete é nosso ônibus, sendo que toda esta complicação teria sido evitada se, de início, eu tivesse perguntado pelo comboio.

$[\ldots]$

Foi para evitar mal-entendidos que, ainda na praia da Nazaré, o copeiro da pensão encerrou assim nosso diálogo:

- Seu Leandro, esta noite os pernilongos não me deixaram dormir.

- Perdão, minha Sra.?

- Os mosquitos, Seu Leandro.

- Ai, V. Excia. quer dizer os melgas? ...

- Não sei se são melgas, mas diga-me, aqui há maleita?

- Perdão, minha Sra.?

- Digo malária ...

O homem olhou-me de banda e teve uma inspiração:

- V. Excia. não prefere falar em francês ou inglês? ... 
Tinha razão o bom do homem. Assim que abandonamos o vernáculo nos entendemos perfeitamente. ${ }^{372}$

O humor do texto se apoia nessa percepção da existência do oposto da compreensão que se esperava encontrar entre povos que em teoria falam a mesma língua e na esdrúxula proposta para solucionar o problema.

\section{Riem dos homens}

\section{Márcia Denser, O vampiro da Alameda Casabranca ${ }^{373}$}

No capítulo anterior, mencionou-se a suposição de que homens e mulheres lidam com a produção de humor de formas diferentes e que algumas características do modo como a mulher faz humor seriam: a comédia feminina é menos hostil, pois as mulheres tendem a se autodepreciar mais do que desqualificar o outro; o alvo do humor produzido por mulheres é mais o poderoso do que o desprezível; as mulheres costumam rir menos da dor e do embaraço dos outros ${ }^{374}$.

Este conto é outro exemplo de que o humor que a mulher escreve pode ser hostil, cáustico, desmoralizante, negando os traços "humanitários" que o caracterizariam. Por ter o seu humor construído, principalmente, a partir da depreciação, é necessário mostrar a escolha de vocabulário pejorativo, a construção de comparações escatológicas, principalmente aquelas que se referem ao poeta Klaus, cujas motivações mais mesquinhas, a narradora parece se comprazer em expor:

372 JORDÃO, 1969, p. 424-425.

373 DENSER, M. O vampiro da Alameda Casabranca. In: MORICONI, Í. (Org.). Os cem melhores contos brasileiros do século. Rio de Janeiro: Objetiva, 2001. p. 393-401.

374 BARRECA, 1991, p. 1-37. 
A não ser pelo filme japonês em cartaz, não havia nenhum interesse em sair com aquele sujeito, poeta, que se ostentava como "maldito" só para poder filar seu canapezinho de caviar nas altas rodas. Um guru de fachada, meio sobre o charlatão cósmico, adepto que era de uma esotérica seita oriental, babaca como tantas outras, e usando tudo isso em proveito próprio. Pelo menos não era burro. [...] Feioso, devia viver faminto de carne fresca mas, passando-se por espiritual, ia tirando suas casquinhas. ${ }^{375}$

Além de hipócrita e charlatão, Klaus ostenta uma impressionante pobreza de expressividade, ainda mais para um homem que se diz poeta:

O tal filme japonês fora realmente bom [...], mas o Poeta apenas emitiu suas impressões assim: "É barra! Que barra! É uma barra!" dizendo-as de maneiras diferentes e empostando a voz num diapasão enfático que partia da traquéia, explodindo num ruído seco e rouco, feito um peido bucal, e como se a palavra "barra" contivesse, não digo o significado de todo o universo, mas, pelo menos, de todo o filme. Isso no fim da fita. Durante esteve todo o tempo tentando pegar no meu braço. Um verdadeiro saco. Então eu me perguntava: por que sair com aquele cara? ${ }^{376}$

Isso sem falar de seus traços estilísticos, dermatológicos e capilares francamente desfavoráveis:

Então, ele me submeteu a mais duas horas de suas poesias, aliás inéditas. Se fossem boas até que valeria o esforço, o fascínio, a atenção fingida (tinha ganas de estourar de rir cada vez que ele pigarreava, afivelando um ar circunspecto, como se preparando para ler um discurso, um obituário, um testamento, enfim, algo muitíssimo sério), o vinho, aquele apartamento, o filme japonês, os feriados, aquelas

375 DENSER, 2001, p. 393.

376 Ibid., p. 394. 
profundas crateras que lhe sulcavam o rosto, o ligeiro cheirinho oleoso e adocicado que se desprendia delas, a mania de falar de si próprio na terceira pessoa, como se fosse um fantasma, o fato de ser careca de um lado só, daí o cabelo restante se amontoar num topete atrás da orelha esquerda, enfim, mas não eram. Não eram mesmo. Ocas, delírios vagos, desconexos, de um concretismo de cabeça dura e reticências. Na mesma construção e com a mesma ênfase conviviam vísceras e sangue, cosmos e eternidade, como se essas palavras não significassem nada além de meros sons poéticos convencionais. ${ }^{377}$

A primeira impressão que se tem à leitura do texto é "metralhadora giratória", no sentido de que todos são alvos do humor cáustico da narradora: do poeta, Klaus, alcunhado de o vampiro da Alameda Casabranca, até ela própria. Mas, a uma leitura mais atenta, percebe-se a inadequação de comparar suas observações mordazes a uma metralhadora; o seu olhar, como se usasse uma lente de aumento, esquadrinha a vítima muito de perto e requer um instrumento de maior precisão, como um bisturi, para vivisseccioná-la.

\section{Martha Medeiros, Mamãe Noel}

Já se mencionou várias vezes ao longo deste trabalho a proposta de Mendes de identificar na comédia não a recorrência de temas e técnicas, mas a existência de um método de representação que põe em cheque verdades e garantias através da diversão, definindo assim o método do cômico, por meio do qual é possível desconfiar e zombar das verdades, parodiar os discursos sérios e, também, se divertir com isso ${ }^{378}$.

É isso que se julga perceber no texto de Martha Medeiros, Mamãe Noel $^{379}$, um golpe de misericórdia em qualquer crença que porventura

377 DENSER, 2001, p. 395.

378 MENDES, 2001, p. 332-334.

379 MEDEIROS, M. Mamãe Noel.[S.l.], [200-?] Disponível em: <http://www.releituras.com/ 
ainda se tivesse na existência de Papai Noel. Não porque ele seja uma lenda ou uma crendice infantil e vá de encontro ao pensamento racional das pessoas sensatas. Muito menos porque isso não passe de um "engodo americano-capitalista" para promover as vendas de fim de ano. Não é nada disso. Ele não existe simplesmente porque as características e tarefas do personagem são incompatíveis com o ser homem:

Sabe por que Papai Noel não existe? Porque é homem. Dá para acreditar que um homem vai se preocupar em escolher o presente de cada pessoa da família, ele que nem compra as próprias meias? Que vai carregar nas costas um saco pesadíssimo, ele que reclama até para colocar o lixo no corredor? Que toparia usar vermelho dos pés à cabeça, ele que só abandonou o marrom depois que conheceu o azul-marinho? Que andaria num trenó puxado por renas, sem ar-condicionado, direção hidráulica e air-bag? Que pagaria o mico de descer por uma chaminé para receber em troca o sorriso das criancinhas? Ele não faria isso nem pelo sorriso da Luana Piovani! Mamãe Noel, sim, existe.

$[\ldots]$

Enquanto Papai Noel distribui beijos e pirulitos, bem acomodado em seu trono no shopping, quem entra em todas as lojas, pesquisa todos os preços, carrega sacolas, confere listas, lembra da sogra, do sogro, dos cunhados, dos irmãos, entra no cheque especial, deixa o carro no sol e chega em casa sofrendo porque comprou os mesmos presentes do ano passado?

Por trás do protagonista desse megaevento chamado Natal existe alguém em quem todos deveriam acreditar mais. ${ }^{380}$

Ao expor sua tese da impossibilidade de existência de um Papai Noel do gênero masculino, ela o faz mostrando a discrepância existente

mamedeiros_noel.asp >. Acesso em: 28 abr. 2007.

380

MEDEIROS, [200-7]. 
entre os atributos necessários para dar conta do recado e aqueles que os homens têm a oferecer. Não contente com isso, a autora revela quem realmente faz o trabalho pesado por trás da mise-en-scène do bom velhinho.

\section{Riem de Deus e o mundo}

Hilda Hilst, Como se um brejeiro escoliasta...

Lendo e relendo o livro Cascos \& carícias, de Hilda Hilst, na tarefa de escolher uma crônica para incluir neste texto, percebeu-se, nos títulos, nos parágrafos iniciais e nas crônicas, de modo geral, uma recorrência de perguntas e questionamentos. Só para dar uma ideia da constância do método, a primeira crônica se intitula: Por que não?; a segunda, Por que, hein?; a terceira inicia-se por: "Às vezes, me perguntam o porquê de eu ter optado pelo riso depois de ter escrito as minhas ficções, meu teatro, minha poesia, com grandes e constantes pinceladas de austeridade?"; a quarta, por sua vez, "A perplexidade de pertencer à raça humana. O que quer dizer ser humano? Os canalhas são humanos? Os santos são humanos?"

O que se percebe é que Hilda Hilst faz uso sistemático do método cômico, desconfiando de certezas garantidas, zombando do sério, pondo em cheque a estabilidade das posições. O texto escolhido não foge à regra. Logo no início da crônica, ela pergunta:

E por que será que todas as coisas ligadas à santidade são necessariamente ligadas ao sofrimento? Por que é preciso flagelar-se, jejuar, maltratar o corpo, mutilar-se, dar todos os bens, ser um pária na vida? Por que os humanos inventaram um deus ou deuses sempre ameaçadores, ávidos por sangue e martírio, as bochechas inchadas de tanto triturar a carne das criaturas? 381

381 HILST, 1998, p. 20-22. 
Ela não apenas questiona o asceticismo e/ou a cruência sacrificial de seitas e religiões, mas também reduz a divindade a uma invenção humana e, não apenas humana, mas cruel, grotesca e cômica, traduzida na imagem de um deus vampiresco, canibal e glutão, com as bochechas estufadas de carne de bicho e de gente.

As supostas ordens provindas de Deus para torturar, esfolar e queimar na fogueira não passariam, segundo ela, de falhas na comunicação causadas por um ruído no canal entre emissor e receptor ou, muito mais provavelmente, causadas pelo precário entendimento humano:

O conceito de martírio, holocausto, sofrimento para dar prazer a um deus é para mim inaceitável. O que pensar dos neurônios de Isaac [sic] entendendo que era para pôr o filho na fogueira? Todos esses supostos diálogos dos humanos com um suposto deus me lembram a Telesp em dia de chuva, você chamou Londres e te dão Carapicuíba ou Cururu-Mirim. Ninguém entendeu nada até agora (como na microfísica) e os humanos têm mesmo, segundo a Ciência, muitos parafusos soltos entre o neocórtex e o hipotálamo. ${ }^{382}$

Tendo posto em dúvida os fatores da comunicação entre a divindade e o homem, ela desconfia também da eficácia da missão do enviado de Deus à Terra:

Não me conformo também com isso de um deus mandar seu filho para o planeta Terra a fim de ser crucificado. Pra nos salvar, me ensinaram. Mas nós não fomos salvos de nada! Continuamos os mesmos estúpidos paranóicos (é só ler a História) em direção à loucura, ao pânico, ao desespero. Como é que você pode entender alguém que te diz: "sim, meu amor, eu te amo, mas aguenta firme que vou te arrancar as unhinhas, aguenta firme que vou te furar os óinho, aguenta firme que vou te crucificar". [...]. Se Deus fosse só um amante enciumado e eu o traísse com o chifrudo, até dá pra entender. $\mathrm{O}$

382 Ibid. p. 20. 
sexo é ligado a muitas fantasias sórdidas. Ou vocês só fazem aquele buraco no lençol? Alguém muito especial me dizia: tens um inimigo? Deseja-lhe uma paixão. Mas a luz lá de cima, o grande sol das almas me condenando ao sofrimento, me pentelhando para sempre a vida? Ah, não. ${ }^{383}$

A narradora parece perceber que os caminhos da salvação pela conversão, tal como algumas religiões as compreendem, tendem ao trágico, já que, muitas vezes, isto costuma passar por sectarismo, discriminação, culpa, expiação, arrependimento, formando uma espécie de cadeia semântico-ideológica que não tem levado a humanidade muito longe da ignorância, da paranoia e da intolerância.

Cleise Mendes observa, a esse respeito, que ainda persiste a crença na existência de uma correlação necessária entre "ascetismo e conhecimento, dor e reflexão, seriedade e verdade, sofrimento e transcendência, num imbróglio cristão-platônico" que ainda continua surtindo efeito ${ }^{384}$.

Mendes e Hilst, cada uma no seu estilo, parecem estar de acordo quanto à ideia de que o modo cômico de responder ao mundo ainda não foi suficientemente validado quanto o trágico e de que o primeiro pode ser igualmente (ou mais) eficaz para exorcizar fantasmas e preencher a falta e o desejo. Ambas, de alguma forma, creem que o cômico "salva", mas entre aspas, claro, não como o que converte, mas como o que diverte. Mendes diz: "Creio que o cômico nos 'salva' - momentaneamente, é claro, porque festa é festa, mas o que é que salva para sempre? - desse eixo trágico de culpas e desculpas" 385.

Hilda Hilst, por sua vez, afirma que se voltou para o humor porque optou pela sua própria salvação, "porque mora na morte. Aquele que procura Deus na austeridade" 386 .

383 HILST, 1998, p. 20-22.

384 MENDES, 2001, p. 332.

385 MENDES, 2001, p. 332.

386 HILST, 1992, p.15. 


\section{Rachel de Queiroz, Viagem de bonde}

Voltando o olhar para as coisas visíveis e risíveis do mundo, o texto de Rachel de Queiroz, Viagem de bonde ${ }^{387}$, é uma crônica, no sentido de um texto que reúne observações sobre o cotidiano de maneira breve, leve e bem humorada. Ele trata de uma viagem de bonde no Rio de Janeiro da década de 1950. Há vários elementos que poderiam ser destacados no que se refere ao humor: o pitoresco dos personagens, as queixas contra o governo que não mudam, a irônica conclusão de que, mesmo sem luz, sem água e sem transporte, o Rio de Janeiro é comparado ao paraíso.

Entre eles, há dois que parecem ressaltar e que serão comentados. O primeiro deles é o contraste entre a exiguidade do espaço disponível no bonde já superlotado e o otimismo da crença dos seus ocupantes de que, empurrando sempre encaixa, sendo que quem tenta se encaixar é uma baiana de quase 90 quilos sem os adereços, o tabuleiro, o fogareiro, o tamborete e a cunhã:

E tratava de acomodar-se gingando os ombros e os quadris à direita e à esquerda, quando o bonde parou em outro poste, o soldado repetiu o tal slogan do encaixe, e foi subindo - logo quem! - uma baiana dos seus noventa quilos, e mais uma bolsa que continha o fogareiro, a lata dos doces, o banquinho e o tabuleiro. E aquela baiana pesava os seus noventa quilos mas era nua, com licença da palavra, pois com tanta saia engomada e mais os balangandãs, chegava mesmo era aos cem. E esqueci de dizer que junto com ela ainda vinha uma cunhãzinha esperta que era um saci, que se insinuou pelas pernas do pessoal e acabou cavando um lugarzinho sentada, na beirinha do banco, ao lado de uma moça carregada de embrulhos e que assim mesmo teve o coração de arrumar a garota. Também o diabo da pequena conquistava qualquer um, com aquele olho preto enviesado, o riso largo de dente na muda. ${ }^{388}$

387 QUEIROZ, R. Viagem debonde. [S.1.], [200-?]. Disponível em: <http://www.releituras. com/racheldequeiroz_bio.asp>. Acesso em: 28 abr. 2007.

388 QUEIROZ, [200-?] . 
Outro aspecto lúdico deste texto é o jogo que se percebe entre a forma do texto imitando o espaço de um bonde apinhado de gente, onde a narrativa se passa, e o assunto sobre o qual ela trata. A maior parte do texto está dividida em dois grandes parágrafos, como se fossem os dois grandes vagões do bonde: o carro-motor e o reboque. As sentenças são encadeadas por marcadores coesivos, principalmente o conectivo "e", como se as frases coladas umas às outras mimetizassem a proximidade das pessoas nos vagões abarrotados.

\section{Lúcia Carvalho, A máquina}

Outro texto cujo humor está voltado para as coisas do mundo é o de Lúcia Carvalho, A máquina ${ }^{389}$. Transformado, graças à sua versatilidade, em eletrodoméstico, o computador deve ter substituído, nos últimos 20 anos, hábitos centenários como os de jogar paciência com cartas de baralho, fazer apresentações com transparências e bater textos à máquina. Porque é óbvio que, analisando as opções sob a lógica positivista do progresso, a paciência digital é mais prática do que a analógica, não é necessário, por exemplo, embaralhar as cartas; é evidente que os slides do power point no data show são infinitamente mais eficientes do que transparências de retroprojetor; e quanto a bater textos à máquina, nem é bom falar, esta seria uma boa razão, por exemplo, para se desistir de concluir, ou melhor, de iniciar uma tese de doutorado. No que diz respeito a esta pesquisadora, o computador substituiu com ampla margem de vantagem, em tudo, a máquina de escrever. Será?

O texto se passa na casa de uma tia falecida, onde uma mãe e seus filhos estão separando as coisas que serão divididas entre os parentes. A menina de 12 anos e seu irmão menor encontram uma velha máquina e tentam explicar para a mãe como o achado funciona:

389 CARVALHO, L. A máquina. [S.1.], [200-?]. Disponível em: <http://www.releituras.com /luciacarvalho_amaquina.asp >. Acesso em: 28 abr. 2007. 
- Deixa que eu falo: é assim, é uma máquina, tipo um ... teclado de computador, sabe só o teclado? Só o lugar que escreve? - Sei.

- Então. Essa máquina tem assim, tipo uma impressora, ligada nesse teclado, mas assim, ligada direto. Sem fio. Bem, a gente vai, digita, digita...

Ela ia se animando, os olhos brilhando.

- ... e a máquina imprime direto na folha de papel que a gente coloca ali mesmo! É muuuito legal! Direto, na mesma hora, eu juro!

Ela jurava? Fiquei muda. Eu que jurava que não sabia o que falar diante dessa explicação de uma máquina de escrever, dada por uma menina de 12 anos. Ela nem aí comigo. Continuava.

- ... entendeu como é, ô mãe? A gente, zupt, escreve e imprime, até dá para ver a impressão tipo na hora, e não precisa essa coisa chatérrima de entrar no computador, Iigaaar, esperar hóóóras, entrar no word, de escrever olhando na tela e sóóó depois mandar para a impressora, não tem esse monte de máquina tuuudo ligada uma na outra, não tem que ter até estabilizador, não precisa comprar cartucho caro, nada, nada, mãe! É muuuito legal. E nem precisa de colocar na tomada! Funciona sem energia e escreve direto na folha da impressora! ${ }^{390}$

O humor, então, é construído a partir desse estranhamento do cotidiano e da inversão da lógica de que o novo é sempre melhor do que o velho, o texto questiona a noção de superioridade absoluta do computador em relação às antigas Remingtons e Olivettis. E isso não sob a ótica reacionária de algum saudosista de plantão, mas justamente aos olhos da geração que, tendo nascido depois do computador pessoal, nunca tinha visto uma máquina de escrever e, por isso, conseguem perceber as vantagens, por assim dizer, que as velhas máquinas tinham, mas que a geração que as descartou já nem lembrava mais.

390 CARVALHO, [200-?]. 


\section{Zulmira Tavares, A curiosa metamorfose pop do Senhor Plácido}

No texto de Zulmira Tavares, A curiosa metamorfose pop do Senhor Plácido ${ }^{391}$, o gerente de uma loja de eletrodomésticos, Plácido, deve, num mesmo dia e nessa ordem, comprar um penico de plástico, ir à Bienal de Arte Moderna, comparecer a um enterro e coletar suas próprias fezes para exame laboratorial.

Pode-se dizer que o humor desse texto se constrói a partir do recurso da interferência de séries ou do fato de uma situação pertencer ao mesmo tempo a duas séries de acontecimentos independentes e poder ser interpretada, ao mesmo tempo, em dois sentidos diferentes ${ }^{392}$.

Relutando em ir à exposição por se considerar por fora de tudo, é aconselhado a chegar à Bienal inocente e procurar não a eternidade, mas a transitoriedade. Carregando consigo, pois, seus olhos inocentes e o seu penico rosa de plástico, Plácido vai transitar entre o cemitério, a exposição de arte e o sanitário, tomando um pelo outro, deslocando suas interpretações, borrando os seus limites.

Pela primeira vez em sua vida o Sr. Plácido se observa. Agora, nesse momento. Inclinado para a frente, despido da cintura para baixo, as pernas finas e cabeludas ligeiramente abertas, as nádegas imensas e brancas apoiadas na pequena e leve circunferência rosa. Tem ele a impressão de ser este o único apoio para o seu corpo, que os seus pés mal tocam o chão; paira. Dois pares de aspas, como frágeis mãos, colhem-no por baixo, delicadamente, pelas nádegas e guardam-no consigo. Novos limites? Não pode evitar. Exatamente como descreve o catálogo. Está no catálogo. Colhido pelas aspas como dentro de uma cápsula, aguarda a revelação; uma revelação de ponta-cabeça; mas que, se vier, fugirá imediatamente a este estado de graça pois que de pronto será encaminhada

391 TAVARES. A curiosa metamorfose pop do senhor Plácido. In: COSTA, F. M. (Org.). Os 100 melhores contos de humor da literatura universal. Rio de Janeiro: Ediouro, 2001. p. 517-521.

BERGSON, 2001, p. 71. 
ao laboratório para exame. Arte e ciência. Arte e não-arte! Os limites depostos, outra vez? As respostas acham-se retidas dentro da cápsula com o Sr. Plácido. O sinal da revelação ainda é apenas o roxo na sua fisionomia congesta. O sinal é esforço, mas esforço suspenso, sem quase apoio, roxo, roxo-solferino. A suspensão é auréola: o plástico rosa, frio e leve. Um precário estado de graça iluminado. Pelos antípodas: roxo violento, rosa tênue. Duas cores, ou uma: dois tons, ou um

$$
\begin{aligned}
& \text { puro } \\
& \text { perfeito } \\
& \text { objeto } \\
& \text { pop. }^{393}
\end{aligned}
$$

Mais do que narrado, pois a voz narrativa quase desaparece, o quiproquó aqui é construído pelo diálogo entre a inocência de Plácido e a expertise dos seus interlocutores: o vendedor de penicos, o seu amigo entendido em arte, sua esposa. Ao final, quando a voz retoma a narrativa para concluí-la, ela faz convergir as séries: a vida, a arte e o corpo para o penico, signo que aponta para o que é provisório, precário e perecível, por excelência. Aqui o que o humor faz ressaltar é o contraste entre a natureza abstrata, delicada, por que não dizer, quase espiritual, das palavras escolhidas - "rosa", "frágeis", “delicadamente”, "Arte”, “Ciência, "paira”, "revelação", "estado de graça iluminado" - e o alto grau de iconoclastia e escatologia encenadas.

\section{Riem da morte}

Para Propp, nada que seja sublime pode ser ridículo, ridícula é a sua transgressão, que se pode materializar em uma particularidade que torne uma pessoa diferente do seu meio ou em uma infração das normas de conduta da coletividade, mas para que isto seja visto 
como um defeito cômico, é necessário que não cause nem ofensa, nem revolta, nem piedade e nem compaixão ${ }^{394}$.

Para saber se a sugestão de que algo sublime pode estar a salvo do cômico é pertinente, buscou-se a palavra "sublime" no Aurélio Séc. XXI e encontrou-se a seguinte definição: "que atingiu um grau muito elevado na escala dos valores morais, intelectuais ou estéticos; quase perfeito". Este "quase" é uma rachadura na redoma do sublime, é o lugar ideal para o modus operandi do cômico encaixar a alavanca do seu ângulo de visão e desestabilizar a divisória que separa o risível do não-risível.

A ideia de que haja algo a salvo do cômico não se sustenta, porque o ridículo não está tanto naquilo que é representado (falhas, defeitos, desvios de conduta) quanto no modo de ver do cômico que, por olhar de baixo, desconfia dos pretendentes ao sublime e se compraz em atrair para baixo tudo que caia no seu ângulo de visão ${ }^{395}$.

A participação do espectador nesse jogo vai depender de uma licença ética para aceitar a inverossimilhança da abordagem do tema e para acreditar, como exige a fantasia cômica, que se pode jogar com tudo, mesmo com as imagens da morte ${ }^{396}$.

\section{Cora Coralina, em O lampião da Rua do Fogo}

É o que faz Cora Coralina, em O lampião da Rua do Fogo ${ }^{397}$. Trata-se da história de dona Placidina e seu Maia, ele porteiro da Intendência, boa pessoa, serviçal, um santo homem se não fosse o gosto pela pinga. Ela, dona de casa, de primeira, esposa exemplar, mas já um pouco cansada e desiludida das bebedeiras do marido, desejando, em seu íntimo, uma boa morte para si mesma ou, o que seria melhor, para ele.

394 PROPP, 1992, p. 59-65.

395 MENDES, 2001, p. 147-150.

396 Ibid., p. 315-317.

397 CORALINA, C. O lampião da Rua do Fogo. In: CORALINA, C. Estórias da casa velha da ponte. 11. ed. São Paulo: Global, 2001. p. 63-72. 
Lá um dia, seu Maia adoece e, apesar dos cuidados do médico e da solicitude da esposa, morre. Na saída do enterro, desaba um temporal, e, por conta da chuva e de um poste mal localizado, os carregadores derrubam o caixão e, com o baque, o morto volta a si. Em meio ao assombro das gentes e da gritaria dos moleques, o ex-defunto volta para casa e para os cuidados relutantes da ex-viúva. Meses depois, seu Maia adoece e morre novamente, o médico, por via das dúvidas, só autoriza o enterro quando o defunto começa a feder.

Resumido às linhas gerais do enredo, o conto é um caso ou "causo", uma anedota sobre o defunto por engano, o que, a depender dos matizes que lhe são atribuídos, pode se tornar engraçado, trágico ou grotesco. Neste caso específico, o tom é leve e bem-humorado.

Ao entremear a história com os usos e costumes das doenças, velórios e enterros da Goiás de antigamente, a narradora despe a morte de sua mortalha trágica, e às vezes grotesca, e a reveste de acontecimento triste e inevitável, é verdade, mas cotidiano, singelo, rotineiro. É como se o impacto irremediável da morte se diluísse, aos poucos, no transcorrer das pequenas providências práticas e corriqueiras.

Se bem que, no conto, a morte não é tão irremediável assim já que o pseudomorto volta a si, quando o caixão onde está sendo carregado colide com um lampião. A ressurreição recebe o mesmo tratamento dado à morte. O que poderia ser pretexto para lances dramáticos e grandiloquentes é na verdade tratado como se fosse uma trapalhada, e toda a cena adquire um certo ar farsesco ao mostrar seu Maia de meias, com um pano amarrado no queixo, voltando para casa debaixo de chuva, acompanhado pelos moleques, gritando: "é vem o defunto".

O caráter prosaico e caseiro atribuído a essa morte deve-se, talvez, à natureza de dona Placidina que "era muito prática nessas e noutras coisas". Se o marido chegava bêbado, ela ajeitava logo um café amargo com semente de jurubeba e o empurrava para a rede. Quando ele morre, passadas as apropriadas vertigens da viuvez recente, ela volta a si, faz das tripas coração e passa a cuidar dos que vieram para a sentinela: café com biscoito, mexido de lombo de porco com farofa e requentão. 
O pragmatismo da personagem contribui também para o humor do conto. Na sua secreta ânsia de livrar-se do marido, mas sendo uma esposa exemplar, tudo que ela podia fazer era esperar, em segredo, pela viuvez. Tendo visto seu desejo secreto atendido e, logo, desfeito pelas trapalhadas do compadre, ela, que de jeito nenhum quer ver sua viuvez novamente frustrada, não esquece de advertir o carregador do caixão: “- Compadre Mendanha... Escuta, compadre, cuidado com o lampião da Rua do Fogo, viu... Não vá acontecer como da outra vez..." 398

\section{Riem até do diabo}

\section{Anônima, Artes de Branca Flor}

Como costureira, a especialidade de minha avó paterna era fazer colchas de retalhos. Ela os separava primeiro por cores e texturas, depois juntava os pedaços com a mesma padronagem, fazendo umas tiras compridas, que finalmente, unia e transformava num belíssimo mosaico de pano colorido. Na cozinha, ela tinha mão boa para pãezinhos de forma, fofos, cheirosos, passados no queijo ralado ainda pelando de quente. Agora, dom de verdade ela tinha era pra contar estórias. Que ela ia contando e andando pela cozinha, medindo as colheradas de fermento e açúcar e as xícaras de farinha e leite morno, levando os netos atrás como o flautista de Hamellin. Ou, então, sentada, costurando, marcando o ritmo com o nhec, nhec da máquina. Eram estórias de todos os tipos, de bicho, de assombração, de fadas, de esperteza, entre as quais uma das mais interessantes era Artes de Branca-Flor ${ }^{399}$.

O conto é a história de um rapaz viciado em jogo que, uma noite, perde numa aposta a própria sombra para o diabo. Para reavê-la, ele tem que ir buscá-la na Montanha Negra, onde vai passar

398 CORALINA, 2001, p. 72.

399 GUIMARÃES, 1964, p.35-46. 
por uma série de provas e peripécias com a ajuda de Branca-Flor, a filha do capeta.

Embora a história tenha as características dos contos maravilhosos, tal como Propp ${ }^{400}$ os classifica, ela tem um aspecto que a distingue da maioria, que é o fato de ser um dos poucos em que a filha (ou o filho), em vez de ser a vítima inocente de uma madrasta malvada ou de um pai incestuoso, tem consciência de que eles significam um obstáculo ao seu desejo que ela precisa superar. No caso de Branca-Flor, isso é feito sem o uso da força e sem a ajuda da varinha de condão, mas através do uso de sua própria astúcia. E é nisso que reside o humor do texto, nas artimanhas que ela utiliza para fazer o pai de tolo.

O princípio de fazer o diabo de bobo está presente em outros contos populares, como os de Pedro Malasartes, por exemplo. Só que nas histórias de Malasartes, ele costuma fazer isto em proveito próprio, para ficar rico ou se tornar imortal, enquanto Branca-Flor o faz para salvar a própria vida e a de seu companheiro. Outro aspecto peculiar e humorístico da história é o aspecto "domesticado" do diabo, cuja esposa, que pelo jeito é quem manda na casa, o considera um "bocó de fivela". É ela quem desvenda as artimanhas que a filha prepara para enganar o pai.

Quando o diabo descobre que a filha ajudou o rapaz a reaver sua sombra, decide matá-los. Ela adivinha o plano e, antes de fugir, coloca um pote de barro cheio de vinho em sua cama e na do seu companheiro, pega um punhado de agulhas da caixa de costura, um pedaço de sabão da despensa, um punhado de cinzas do fogão e cospe nele três vezes.

O diabo espera dar meia-noite para executar sua vingança e chama a filha para ver se ela já está dormindo. Um cuspo, no fogão, responde: "Já vou". Ele espera mais uma hora e chama novamente, outro cuspo, já mais fraco, responde: "Já vou". Espera mais um pouco, e quando chama, o cuspo já quase seco responde um “já

400 PROPP, Vladimir. Morfologia do conto maravilhoso. Tradução de Jasna Paravich Sarhan. Rio de Janeiro: Forense Universitária, 1984. p. 85. 
vou" de quem já está quase dormindo ${ }^{401}$. Nesse tipo de expediente percebe-se a peculiaridade das artes de Branca-Flor: elas são mais lúdicas e mais astuciosas do que os meios mágicos convencionais, como uma varinha de condão, ou do que as palavras mágicas, como o "Abre-te, ó Sésamo". O que ela faz é tornar concreto o figurado; é materializar o metafórico ou, no caso dos cuspos, o metonímico.

Os cuspos são meios mágicos de natureza metonímica, porque a relação que existe entre eles e a sua função não é de similaridade, o que os tornaria metafóricos, mas de contiguidade. Eles obedecem ao princípio da magia contagiosa, segundo o qual as coisas que, em certo momento, estiveram em contato, mesmo que sejam completamente separadas uma da outra devem continuar a agir umas sobre as outras, mesmo à distância, de modo que o que quer que afete uma delas afetará a outra, sendo que um dos exemplos mais conhecidos deste tipo de magia é a simpatia mágica que se supõe existir entre o homem e qualquer parte que tenha sido separada de sua pessoa, como o cabelo ou as unhas ${ }^{402}$.

A astúcia de Branca-Flor está no foco de percepção daquilo que é significativo ou motivado para o propósito da sua magia. Na saliva, que é um meio mágico metonímico, ela dispõe de uma parte que dela pode ser destacada e que dela guarda - por estar sempre em contato com os órgãos vocais - a característica necessária para enganar o pai: a sua voz. Não poderia ser um fio de cabelo, nem um pedaço de unha. E se tratando de Branca-Flor, mais esperta que o próprio diabo, ela não deixaria para trás a língua, como fez a Pequena Sereia, deixou o cuspo.

Em suas viagens, Gulliver chega a Balnibarbi, em cuja capital, Lagado, uma academia de estudiosos planeja abolir todas as palavras e substituí-las pelas coisas que nomeiam:

[...] muitos eruditos e sábios aderiram ao novo plano de se expressarem por meio de coisas, cujo único inconveniente

401 GUIMARÃES, 1964, p. 39-40.

402 FRAZER, J. G. A magia simpática. In: FRAZER, J. G.O ramo de ouro. Rio de Janeiro: J. Zahar, 1982, p. 34-44. 
residia em que, se um homem tivesse de falar sobre longos assuntos e de várias espécies, ver-se-ia obrigado, em proporção, a carregar nas costas um grande fardo de coisas, a menos de poder pagar um ou dois criados robustos para acompanhá-lo. ${ }^{403}$

Branca-Flor é mais sagaz do que os sábios de Balnibarbi, não podendo levar consigo as armadilhas necessárias para aprisionar o diabo, ela leva delas as características necessárias, figurativamente materializadas nos objetos mágicos que escolhe: cinza, agulhas e sabão. São objetos metafóricos, porque, entre eles e os seus respectivos obstáculos, existe um elemento de similitude e, principalmente, existe a qualidade necessária para torná-los capazes de deter o pai: tem-se, pois nas cinzas, o cinzento cerrado de um nevoeiro; nas agulhas, o pontiagudo aguçado de um espinheiro e, no sabão, o escorregadio grudento de um atoleiro:

Papai vem aí - avisou a moça. - Atire para trás o punhado de cinzas.

O moço assim fez e logo se formou um nevoeiro baixo tão espesso quanto uma cortina. Não se enxergava nada. O diabo andou daqui, dali, pererecando, até que conseguiu passar. Quando estava pertinho outra vez, o moço, a mandado de Branca-Flor, atirou o sabão. Formou-se um atoleiro de tijuco preto, tão grudento, que o diabo suou para escapar. Saiu dele enfezado, e foi outra vez atrás dos moços. Quando estava quase a alcançá-los pela terceira vez, o moço jogou as agulhas. Formou-se um espinheiro tão cerrado, que o diabo, aí, não teve remédio senão voltar. ${ }^{404}$

Isso é apenas uma pequena parte da história, mas acredita-se que é suficiente para dar uma ideia dos obstáculos que Branca-Flor enfrenta e dos artifícios que ela usa para superá-los. Para aqueles que

403 SWIFT, J. Viagens de Gulliver. São Paulo: Círculo do Livro, [198-]. p. 177.

404 GUIMARÃES, 1964, p. 41. 
subestimam os perigos encenados no universo cômico, por achar que eles não passam de uma brincadeira inconsequente, Mendes sugere que eles imaginem um final diferente para textos consagrados, como O Mercador de Veneza, e vejam que dar a vida em pagamento de uma dívida seria aterrorizante caso a situação não fosse revertida graças à sorte, à providência ou à astúcia ${ }^{405}$. Sem a esperteza de Branca-Flor, por exemplo, em fugir deixando potes de vinho sob as cobertas, a cena seguinte teria sido cruel:

O diabo deixou passar mais um pouco e tornou a chamar. Ninguém respondeu.

Aí ele se levantou, pegou um pau e foi à cama do moço e malhou até que viu escorrer o que julgou ser sangue. Foi à cama da filha e bateu até ouvir o rumor do que parecia ossos quebrando. Voltou para a cama e a mulher perguntou:

- Estão mortos?

- Estão sim. Escorreu sangue.

- Estão mortos mesmo? Você verificou?

- Os ossos estalaram.

A mulher não acreditou e foi ver. E viu: potes quebrados, vinho escorrendo, e nem sinal, nem do moço, nem da moça. - Fugiram! - gritou. ${ }^{406}$

Voltando a Mendes, ela lembra que foi pela astúcia que Ulisses escapou do ciclope Polifemo, usando uma pele de carneiro e um jogo de palavras - "Meu nome é Ninguém" - e deu o que parece ter sido a primeira gargalhada da literatura ocidental, criando um novo tipo de herói: aquele que escapa da morte não pela força, mas pela burla engenhosa ${ }^{407}$.

Branca-Flor pertence a essa linhagem de heróis. Ela não dispõe de força, mas de engenho. Ela joga com o que, literalmente, tem à

405 MENDES, 2001, p.83.

406 GUIMARÃES, 1964, p. 40-41.

407 MENDES, 2001, p. 84. 
mão: sabão, agulhas e cinzas e acrescenta, acredita-se, um toque de ironia na escolha destes objetos, que podem ser percebidos como "grilhões simbólicos" das tarefas domésticas às quais as mulheres costumavam (muitas ainda costumam) estar presas - o eterno lavar, costurar, cozinhar - para fugir e garantir sua sobrevivência, fazendo o próprio diabo de trouxa.

\section{Riem mais do que se imaginava}

Uma vez que basta um único cisne negro para derrubar a tese de que todos eles são brancos, não se considera nem que seja cedo nem que a amostra seja pequena demais para se concluir que as mulheres estão fazendo uso dos recursos do humor no Brasil. E não é de hoje. Embora Leila Ferreira, Patricya Travassos sejam mais contemporâneas, Vera Pacheco Jordão, Hilda Hilst e Clarice Lispector estão aí há décadas.

Pela amostra que foi vista até aqui, percebeu-se que, na maioria desses textos, o personagem principal é uma mulher e a narrativa gira em torno da luta inglória para deter os efeitos do tempo, manter o corpo perfeito e conseguir o parceiro ideal. Com esses dados, embora ressalvando que não é objetivo deste trabalho traçar diferenças sistemáticas do humor entre os gêneros, o que se pretende fazer, ainda no espaço de conclusão deste capítulo, é uma pequena digressão quanto a este assunto.

Uma das etapas de construção deste texto passou pela análise de procedimentos da construção do humor a partir de textos da antologia Os 100 melhores contos de humor, em que predominavam autores masculinos ${ }^{408}$. Dela, foram analisados cerca de 20 contos de autores que iam de Machado de Assis a Luís Fernando Verissimo, passando por Lima Barreto, Monteiro Lobato e Millôr Fernandes. Esses textos foram utilizados para verificar se os mecanismos arrolados por Propp continuavam vigentes e serviriam para indicar o

408 COSTA, 2001. 
uso dos procedimentos de construção do humor em textos. Desta verificação, observou-se que os procedimentos de humor que Propp depreendeu principalmente do contexto europeu e, particularmente russo, são, mutatis mutandis, encontradiços tanto nos textos de autores quanto de autoras brasileiras.

Observou-se também que a maioria dos protagonistas nos textos escritos por homem é do sexo masculino e a ação principal é o malogro da vontade, como se uma certa impotência estivesse sendo figurada das mais diversas formas: o pronome mal colocado (Monteiro Lobato, O colocador de pronomes); a mentira malograda (Fernando Sabino, O homem nu); a traição desmascarada (João Alphonsus, Uma história de Judas); o empréstimo negado (Machado de Assis, O empréstimo); a promoção frustrada (Victor Giudice, O armário); a mulher inalcançável (Dalton Trevisan, O Vampiro de Curitiba), a revanche que é negada (Moacyr Scliar, O dia em que matamos James Cagney), a traição que é descoberta (Artur Azevedo, $O$ telefone), as salvaguardas que não salvam (Millôr Fernandes, As salvaguardas nem sempre salvam).

Em resumo, o que se observou é que, em termos de estrutura e temática, os textos de homens e mulheres têm muitos pontos em comum e que não se justifica o baixíssimo percentual de textos de mulheres na referida antologia. O que inicialmente foi considerado mais difícil para a consecução deste trabalho que era encontrar e reunir contos em quantidade suficiente para organizar um conjunto significativo de textos revelou-se na verdade como a parte mais fácil e lúdica. Difícil, na verdade, foi limitar os contos a apenas um por autora. Como disse Regina Barreca, na introdução do The Penguin Book of women's humor, a sua antologia não ficou maior, porque ela queria preservar as árvores ${ }^{409}$. As razões aqui apresentadas são de uma outra natureza, o número de textos se limitou a cerca de 20, em nome da factibilidade da análise e da consecução do trabalho. Mas, sem hesitação, pelo menos o dobro do número de autoras poderia ser citado.

A antologia não incluiu, por exemplo, Adriana Falcão, Ana Cristina César, Cecília Meireles, Cintia Moscovich, Cláudia Valli, Dinah

409 Cf. BARRECA, 1996, p. 4. 
Silveira de Queiroz, Elisa Lucinda, Fernanda Young, Gabriela Leite, Gisela Rao, Helena Morley, Judith Grossman, Júlia Lopes de Almeida, Marina Colasanti, Suzana Abranches, as criadoras do site Banheiro Feminino, Marcela Catunda e Andréa Cals, e, ainda, Jô Hallack, Nina Lemos e Raq Affonso ${ }^{410}$, do grupo 02 neurônio; Aninha Franco, na dramaturgia e imprensa baianas; Maria Carmen Barbosa, parceira de Miguel Falabella em suas peças; Rita Lee, na música, na internet e em livro; isto sem falar das ensaístas e colunistas, como Bárbara Gancia, Dora Kramer, Malu Fontes, Marilene Felinto, que estão aí falando de quase tudo com propriedade e senso de humor.

410 AFFONSO, R.; HALLACK, J.; LEMOS, N. 02 neurônio: almanaque para garotas calientes. São Paulo: Conrad Livros, 1999. 